Article

\title{
Hysteretic Tricolor Electrochromic Systems Based on the Dynamic Redox Properties of Unsymmetrically Substituted Dihydrophenanthrenes and Biphenyl-2,2'-Diyl Dications: Efficient Precursor Synthesis by a Flow Microreactor Method
}

\author{
Yusuke Ishigaki ${ }^{1}$, Takanori Suzuki ${ }^{1, *}$, Jun-ichi Nishida ${ }^{1, \dagger}$, Aiichiro Nagaki ${ }^{2}$,
} Naofumi Takabayashi ${ }^{2}$, Hidetoshi Kawai ${ }^{1,}$, Kenshu Fujiwara ${ }^{1}$ and Jun-ichi Yoshida ${ }^{2}$

1 Department of Chemistry, Faculty of Science, Hokkaido University, Sapporo 060-0810, Japan; E-Mails: y_ishigaki@mail.sci.hokudai.ac.jp (Y.I.); jnishida@echem.titech.ac.jp (J.N.); kawaih@rs.tus.ac.jp (H.K.); fjwkn@sci.hokudai.ac.jp (K.F.)

2 Department of Synthetic Chemistry and Biological Chemistry, Graduate School of Engineering, Kyoto University, Kyoto 615-8530, Japan; E-Mails: anagaki@sbchem.kyoto-u.ac.jp (A.N.); tak@mail.sci.hokudai.ac.jp (N.T.); yoshida@sbchem.kyoto-u.ac.jp (J.Y.)

$\dagger$ Present address: Interdisciplinary School of Science and Engineering, Tokyo Institute of Technology, Yokohama 226-8502, Japan

* Present address: Department of Chemistry, Faculty of Science, Tokyo University of Science, Shinjuku 162-8601, Japan

* Author to whom correspondence should be addressed; E-Mail: tak@sci.hokudai.ac.jp; Tel./Fax: +81-11-706-2714.

Received: 13 September 2011; in revised form: 6 October 2011 / Accepted: 10 October 2011 / Published: 26 October 2011

\begin{abstract}
A series of biphenyl-2,2'-diylbis(diarylmethanol)s 3, which have two kinds of aryl groups at the bay region, were efficiently obtained by integrated flow microreactor synthesis. The diols $\mathbf{3 N O / N X}$ are the precursors of unsymmetric biphenylic dications $\mathbf{2 N O} / \mathbf{N X}^{2+}$, which are transformed into the corresponding dihydrophenanthrenes $1 \mathbf{N O} / \mathbf{N X}$ via $\mathbf{2 N O} / \mathbf{N X}^{+\bullet}$ upon reduction, when they exhibit two-stage color changes. On the other hand, the steady-state concentration of the intermediate $\mathbf{2 N O} / \mathbf{N X}^{+\bullet}$ is negligible during the oxidation of $\mathbf{1 N O} / \mathbf{N X}$ to $\mathbf{2 N O} / \mathbf{N X}^{2+}$, which reflects unique tricolor electrochromicity with a hysteretic pattern of color change [color $1 \rightarrow$ color $2 \rightarrow$ color $3 \rightarrow$ color 1 ].
\end{abstract}


Keywords: electrochromism; organic dye; cationic dye; hysteresis; dynamic redox system; reaction integration; flow microreactor

\section{Introduction}

Electrochromism [1] is a representative function of organic redox systems, by which electrochemical input is reversibly transduced into UV-Vis spectral output. A vivid color change is a desirable feature of these systems, and thus the stable cationic dye moieties such as triarylmethyliums [2] have often been adopted for this purpose. During the course of our studies on "dynamic redox systems" [3,4] that undergo reversible $\mathrm{C}-\mathrm{C}$ bond-formation/-breaking upon electron transfer, we found that 9,9,10,10-tetraaryl-9,10-dihydrophenanthrenes (DHP) 1 and biphenyl-2,2'-diylbis(diarylmethylium)s $2^{2+}$ constitute a novel series of electrochromic pairs.

For example, the electron-donating DHPs (1NN, 1OO, 1XX) show absorptions only in the UV region, whereas the corresponding dications exhibit characteristic vivid colors (blue, red, or yellow) depending on the aryl group $\left[\lambda_{\max } / \mathrm{nm}(\log \varepsilon)\right.$ in $\mathrm{MeCN}$ : 661 (4.92), 604 (5.05) for $2 \mathbf{N N}^{2+}$; $539 \mathrm{sh}$ (4.72), 514 (4.87) for $\mathbf{2 O O}^{2+}$; 495sh (3.62) 460 (3.79) for $\mathbf{2} \mathbf{X X}^{2+}$ ] [5,6]. Mechanistic studies have indicated that interconversion proceeds via the biphenyl-2,2'-diyl-type cation radical $\mathbf{2}^{+\bullet}$ as a common intermediate (Scheme 1) [6,7]. For the $C 2$-symmetric derivatives shown above, however, this cation radical intermediate cannot be detected during the oxidation process of $\mathbf{1}$, since $\mathbf{2}^{\mathbf{+}}$ is more easily oxidized than $\mathbf{1}\left[E^{\mathrm{ox}}(\mathbf{1})>E^{\mathrm{ox}}\left(\mathbf{2}^{+\bullet}\right)\right]$. The same intermediate $\mathbf{2}^{+\bullet}$ is also short-lived during the reduction of $\mathbf{2}^{2+}$, since $\mathbf{2}^{+\bullet}$ undergoes facile disproportionation $\left[E_{1}{ }^{\text {red }}\left(\mathbf{2}^{2+}\right) \sim E_{2}{ }^{\text {red }}\left(\mathbf{2}^{2+}\right)\right]$ into $\mathbf{2}^{2+}$ and $\mathbf{2}^{\boldsymbol{*}}$, the latter of which is instantaneously converted to $\mathbf{1}$ by intramolecular $\mathrm{C}-\mathrm{C}$ bond-formation. In this way, two-color switching [color $1(\mathbf{1})<=$ color $2\left(\mathbf{2}^{2+}\right)$ ] is induced upon the application of electrochemical input to redox pairs with $C 2$-symmetry.

Scheme 1. Mechanism of interconversion between $\mathbf{1}$ and $\mathbf{2}^{2+}$.

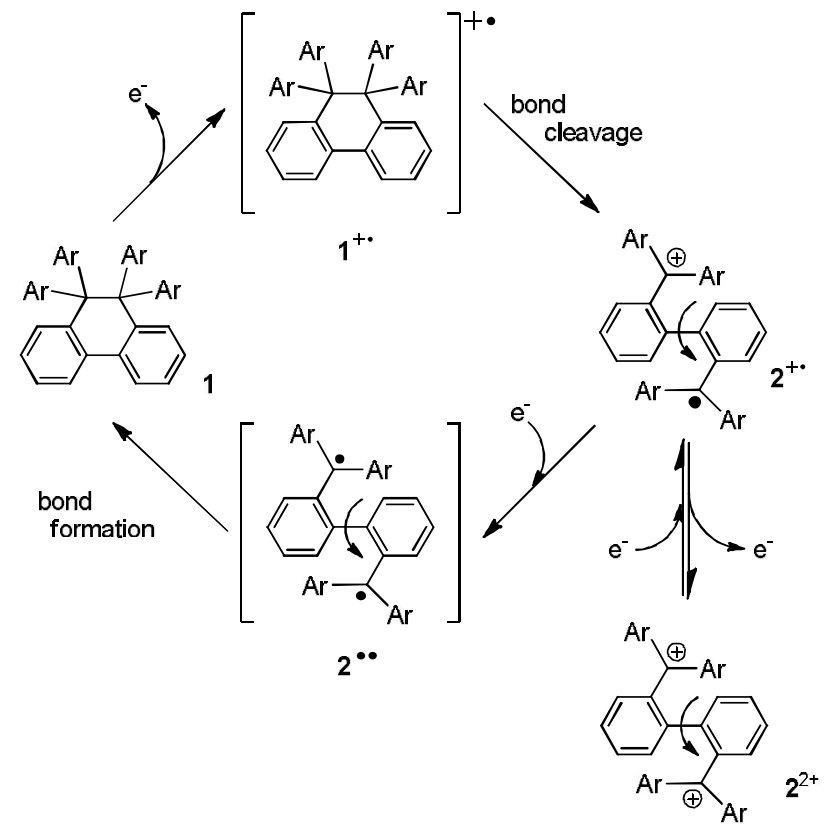


We envisaged that the proper molecular design could incorporate the intermediate $\mathbf{2}^{+\boldsymbol{\bullet}}$ in a novel tricolor electrochromism: disproportionation of $\mathbf{2}^{+\bullet}$ to $\mathbf{2}^{2+}$ and $\mathbf{2}^{* \bullet}$ could be suppressed by attaching two kinds of aryl groups with different electron-donating properties. In this report we describe the preparation and novel electrochromic behavior of unsymmetrically substituted pairs such as $\mathbf{1 N O} / \mathbf{2} \mathbf{N O}^{2+}$ or $\mathbf{1 N X} / \mathbf{2} \mathbf{N X}^{2+}$. Flow microreactor synthesis [8-19] was very effective for sequentially attaching two different diarylmethyl units to the biphenyl skeleton, whereas the conventional macro batch method gave the desired products in low yields (ca. 10\%). The color changes show hysteresis, in that there is a difference between oxidation [color $1(\mathbf{1}) \rightarrow$ color $2\left(\mathbf{2}^{2+}\right)$ ] and reduction [color $\left.2\left(\mathbf{2}^{2+}\right) \rightarrow \operatorname{color} 3\left(\mathbf{2}^{+\bullet}\right) \rightarrow \operatorname{color} 1(\mathbf{1})\right]$.

\section{Results and Discussion}

\subsection{Preparation of Unsymmetrically Substituted Diol-Precursors}

Biphenyl-2,2'-diylbis(diarylmethanol)s 3 are the precursors of dicationic dyes $\mathbf{2}^{2+}$ [5]. Diols with C2-symmetry were readily obtained by reacting diarylketone 4 and 2,2'-dilithiobiphenyl, the latter of which was generated in situ from 2,2'-dihalobiphenyl and 2 equiv. of BuLi at $-78{ }^{\circ} \mathrm{C}$ (Scheme 2) [20]. To prepare unsymmetric diols $\mathbf{3 N O}$ or $\mathbf{3 N X}$ with two different diarylmethane units, we first used a mixture of two diarylketones $(\mathbf{4 N - 4 O}, \mathbf{4 N - 4 X )}$ as an electrophile. Though the desired unsymmetric diols were obtained as a mixture containing two symmetric diols and other byproducts, tedious chromatographic separation only afforded pure $3 \mathbf{N O}$ or $\mathbf{3 N X}$ in respective yield of $12 \%$ and $9 \%$ [6]. Attempts to improve the yield were unfruitful even when dihalobiphenyl was treated sequentially with BuLi (1 equiv.), diarylketone (1 equiv.), BuLi (another 1 equiv.), and another diarylketone (1 equiv.). Again, a mixture of three diols was obtained, since selective monolithiation is difficult under the conventional macro batch conditions even if 1 equiv. of BuLi is used [21].

Scheme 2. Preparation of precursor diols 3 under the macro batch conditions.

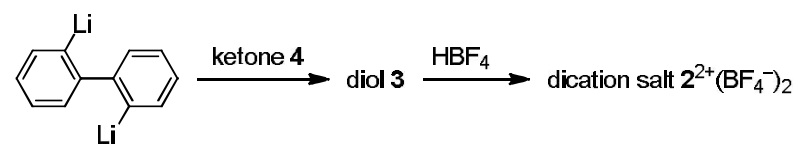

On the other hand, some of us recently demonstrated that monolithiation of dibromobiphenyl can be successfully conducted under the flow microreactor conditions [22,23]. By taking advantage of this process, we succeeded in the sequential introduction of two diarylmethyl units by reaction integration using flow microreactor synthesis [24-26] (Figure 1) thanks to fast micromixing and precise temperature control. The best result was obtained when $0.1 \mathrm{M} 2,2^{\prime}$-dibromobiphenyl in THF (flow rate $6.0 \mathrm{~mL} / \mathrm{min}$ ) was reacted with $0.5 \mathrm{M} \mathrm{BuLi}$ in hexane $(1.2 \mathrm{~mL} / \mathrm{min})$ for $0.06 \mathrm{~s}$ at $24{ }^{\circ} \mathrm{C}$ to generate 2-lithio-2'-bromobiphenyl, which was sequentially reacted with ketone $40(0.2 \mathrm{M}$ in $\mathrm{THF}$, $3.0 \mathrm{~mL} / \mathrm{min})$, BuLi $(0.5 \mathrm{M}$ in hexane, $1.44 \mathrm{~mL} / \mathrm{min})$, and another ketone $4 \mathrm{~N}(0.1 \mathrm{M}$ in THF, $7.2 \mathrm{~mL} / \mathrm{min}$ ). This sequence of reactions proceeded in a short period of $15.5 \mathrm{~s}$, and, unsymmetric diol 3NO with 4-dimethylaminophenyl and 4-methoxyphenyl groups was generated in high NMR yield of $92 \%$ and isolated in 73\% yield after chromatography. Under similar conditions, $\mathbf{3 N X}$ with 4-dimethylaminophenyl and xanthenyl groups was prepared in 81\% NMR yield and isolated in 61\% yield. 
Scheme 3. Formula of compounds

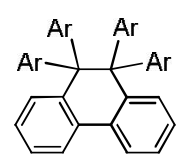

1

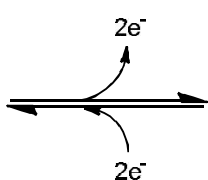

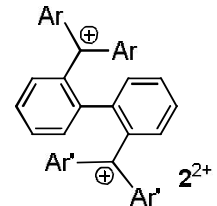

$\mathrm{Ar}^{2}$
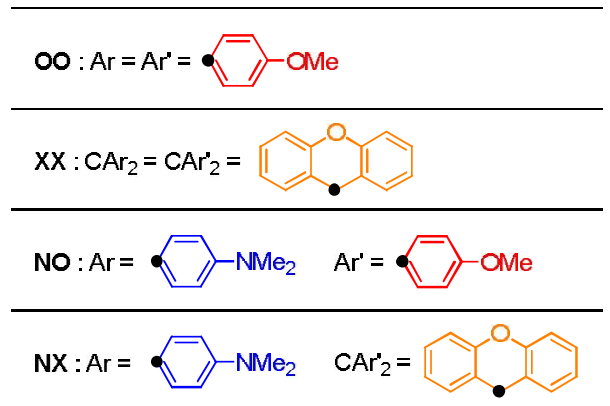

$\mathrm{NO}: \mathrm{Ar}=\left\{-\mathrm{NMe}_{2} \quad \mathrm{Ar}^{\prime}=\square-\mathrm{OMe}\right.$
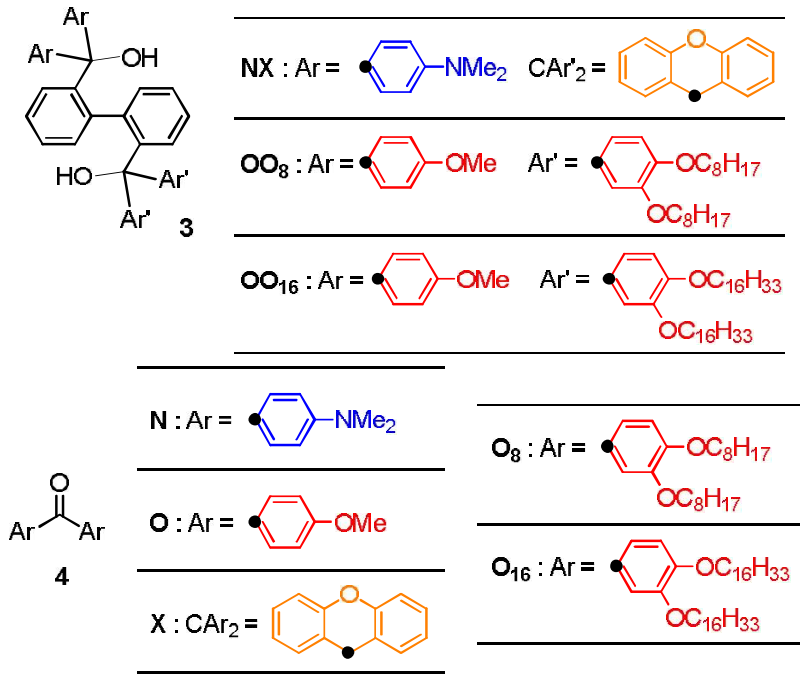

Figure 1. An integrated flow microreactor system for the sequential introduction of two different diarylmethanol units at the 2,2'-position of biphenyl.

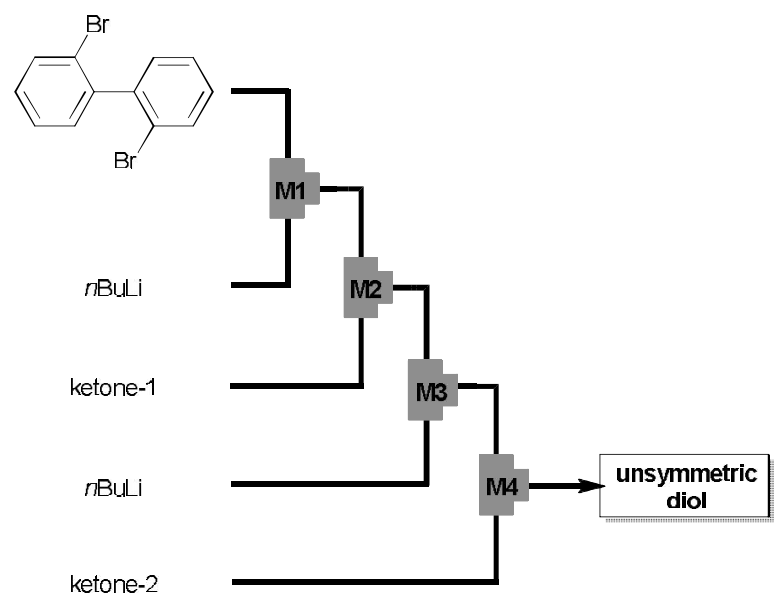


In both $\mathbf{3 N O}$ and $\mathbf{3 N X}$, the two diarylmethyl units differ significantly in terms of their electron-donating properties, so that the combination would be suitable for suppressing the disproportionation of the cation radical intermediate $\left(\mathbf{2} \mathbf{N O}^{+\bullet}\right.$ and $\left.\mathbf{2} \mathbf{N X}^{+\bullet}\right)$ during the electrochemical interconversion of $\mathbf{1}$ and $\mathbf{2}^{2+}$. In addition to its value in preparing the precursors of tricolor electrochromic systems shown above, the flow microreactor method can also produce another group of materials by adopting other bulky diarylketones with long alkoxy chains as an electrophile [e.g., 3,3',4,4'-tetrakis(octyloxy)- or tetrakis(hexadecyloxy)benzophenones, $\quad \mathbf{4 O}_{\mathbf{8}}$ or $\quad \mathbf{4 O}_{\mathbf{1 6}}$ ]. Unsymmetrically substituted diols $\mathbf{3 O O}_{\mathbf{8}}$ and $\mathbf{3 O O}_{\mathbf{1 6}}$ were obtained in good isolated yields of $68 \%$ and $62 \%$, respectively, and could be used to generate unique dicationic dyes that are soluble in a hydrocarbon solvent [7]. The results shown above clearly demonstrate that the flow microreactor system is very effective for the sequential introduction of two bulky substituents at the bay region of the biphenyl skeleton.

\subsection{Preparation and Two-Electron Interconversion of Unsymmetrically Substituted Redox Pairs}

When diols $\mathbf{3 N O}$ and $\mathbf{3 N X}$ were treated with $\mathrm{HBF}_{4}(\mathrm{EtCO})_{2} \mathrm{O}$, deeply colored dications were isolated as stable $\mathrm{BF}_{4}$ salts in respective yields of 91 and $93 \%$. In the UV-Vis spectrum of $\mathbf{2 N O}^{2+}\left(\mathrm{BF}_{4}{ }^{-}\right)_{2}\left[\lambda_{\max } / \mathrm{nm}(\log \varepsilon)\right.$ in $\mathrm{MeCN}: 632$ (4.93), 519 (4.72)], both of the strong absorptions that are characteristic of two different triarylmethyliums are present. Thus, the deep purple color of $\mathbf{2} \mathrm{NO}^{2+}\left(\mathrm{BF}_{4}^{-}\right)_{2}$ solution is due to the simple combination of blue and red chromophores found in $\mathbf{2} \mathbf{N N}^{2+}$ and $\mathbf{2 O O}^{2+}$. Similarly, the green color of $\mathbf{2} \mathbf{N X}^{2+}\left(\mathrm{BF}_{4}{ }^{-}\right)_{2}$ [632 (4.92), $488 \mathrm{sh}$ (3.76), 425 (4.22)] can be accounted for by the presence of the blue and yellow dye units within the molecule.

These dications were cleanly converted into colorless DHPs, $\mathbf{1 N O}$ and $\mathbf{1 N X}$, upon reduction with $\mathrm{SmI}_{2}$ in THF in respective yields of 97 and $78 \%$. The resulting DHPs were reoxidized to $\mathbf{2} \mathbf{N O}^{2+}$ and $\mathbf{2} \mathbf{N X}^{2+}$ by treatment with 2 equiv. of $\left(4-\mathrm{BrC}_{6} \mathrm{H}_{4}\right)_{3} \mathrm{~N}^{+\bullet} \mathrm{SbCl}_{6}{ }^{-}$in $\mathrm{CH}_{2} \mathrm{Cl}_{2}$, which were in turn isolated as deeply colored $\mathrm{SbCl}_{6}{ }^{-}$salts in respective yields of 82 and $79 \%$. This high-yield interconversion indicates that $\mathbf{1 N O} / \mathbf{2} \mathbf{N O}^{2+}$ and $\mathbf{1 N X} / \mathbf{2} \mathbf{N X}^{2+}$ constitute a "reversible" redox pair although $\mathrm{C}-\mathrm{C}$ bond-formation/-breaking is accompanied by electron transfer ("dynamic" redox behavior) $[3,4]$.

According to an X-ray analysis of $\mathbf{1 N X}$ (Figure 2), the C9-C10 bond of the DHP unit [1.643(6) $\AA$ ] is longer than standard (1.54 $\AA$ ) [27], which is due to the "front strain" [28] among the aryl groups at C9 and C10, as in the case of other polyarylated cyclic compounds [29-32]. The DHP skeleton adopts a half-chair conformation with a dihedral angle of $16.2^{\circ}$ for two benzene nuclei, which endows the molecule with an asymmetric element of helicity $(P / M)$. In a single crystal of $\mathbf{1 N X}$ (space group: $P 2{ }_{1} 2_{1} 2_{1}$ ), all of the molecules adopt the same helicity, which shows that spontaneous resolution occurs. Based on the result of a VT-NMR experiment, however, the spectrum indicates $C 1$-symmetry only at low temperature ( $N$-methyl protons: 2.95 and $2.80 \mathrm{ppm}$ in $\mathrm{CDCl}_{3}$ ), and $C$ s symmetry is attained at room temperature $\left(T \mathrm{c}=-40{ }^{\circ} \mathrm{C}\right) . P / M-1 \mathrm{NX}$ readily undergoes racemization due to facile ring-flip in solution $\left(\Delta \mathrm{G}^{\ddagger}=11.4 \mathrm{kcal} \mathrm{mol}^{-1}\right.$ at $\left.-40{ }^{\circ} \mathrm{C}\right)$ (Scheme 4), while this process is prohibited in the crystal. 
Figure 2. Molecular structure of 1NX determined by X-ray analysis: (left) top view; (right) side view. The DHP skeleton adopts a helical geometry, and all of the molecules in a single crystal are homochiral in terms of helicity.
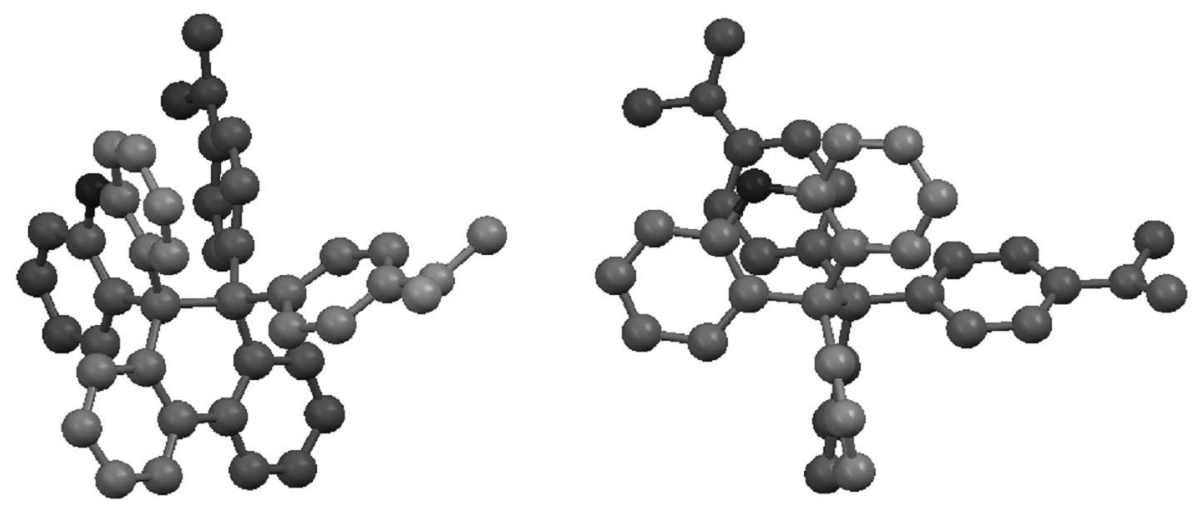

Scheme 4. Interconversion of the enantiomers of helical DHPs 1 by ring flip.

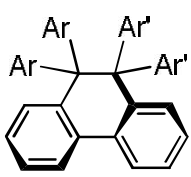

$(P)-1$

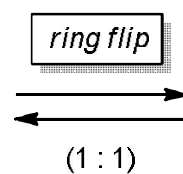

$(1: 1)$

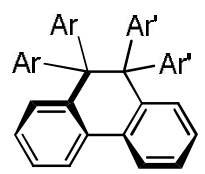

$(M)-1$

\subsection{Hysteretic Redox Behavior of Unsymmetrically Substituted Redox Pairs}

The cyclic voltammograms of C2-symmetric DHPs are similar to each other, with an irreversible 2e-oxidation peak at $+0.77(\mathbf{1 N N}),+1.47(\mathbf{1 O O})$ or $+1.42(\mathbf{1 X X}) \mathrm{V} v s$. SCE in $\mathrm{CH}_{2} \mathrm{Cl}_{2}$, respectively $[5,6]$. The return wave is largely shifted to the cathode, and was assigned to the 2e-reduction peak of $\mathbf{2} \mathbf{N N}^{2+}$ $(-0.45 \mathrm{~V}), \mathbf{2} \mathbf{O O}^{2+}(+0.18 \mathrm{~V})$, or $\mathbf{2} \mathbf{X X}^{2+}(+0.50 \mathrm{~V})$, respectively (Table 1$)$. Similarly, the present unsymmetric DHPs 1NO and 1NX undergo irreversible 2e-oxidation (Figure 3). Their oxidation potentials are close to that of $\mathbf{1 N N}$, indicating that the HOMO level of $1 \mathbf{N O}$ or $1 \mathbf{N X}$ is close to that of 1NN due to the dimethylaminophenyl groups with strong electron-donating properties. The irreversibility of the oxidation wave suggests that the as-generated cation radical, $\mathbf{1 N O}^{+\bullet}$ or $\mathbf{1 N X}^{+\bullet}$, readily isomerizes to $\mathbf{2 N O}^{+\bullet}$ or $\mathbf{2} \mathbf{N X}^{+\cdot}$ by $\mathrm{C} 9-\mathrm{C} 10$ bond fission. In the return cycle of the voltammogram of $\mathbf{1 N O}$ or $\mathbf{1 N X}$, two cathodic peaks were seen: such behavior is quite different from that of $C 2$-symmetric compounds.

Table 1. Redox potentials of $\mathbf{1}$ and $\mathbf{2}^{2+}$ in $\mathrm{CH}_{2} \mathrm{Cl}_{2}{ }^{\mathrm{a}}$.

\begin{tabular}{cccc}
\hline compd. & $\boldsymbol{E}^{\mathbf{0 x}}(\mathbf{1})$ & $\boldsymbol{E}_{\mathbf{1}}{ }^{\text {red }}\left(\mathbf{2}^{\mathbf{2 +}}\right)$ & $\boldsymbol{E}_{\mathbf{2}}{ }^{\text {red }}\left(\mathbf{2}^{+\boldsymbol{c}}\right)$ \\
\hline NO & $+0.83^{\mathrm{b}, \mathrm{c}}$ & $+0.10^{\mathrm{c}}$ & $-0.45^{\mathrm{c}}$ \\
$\mathbf{N X}$ & $+0.76^{\mathrm{b}, \mathrm{c}}$ & $+0.24^{\mathrm{c}}$ & $-0.19^{\mathrm{c}}$ \\
$\mathbf{N N}$ & $+0.74^{\mathrm{b}, \mathrm{c}}$ & $-0.42^{\mathrm{b}, \mathrm{c}}$ & \\
$\mathbf{O O}$ & $+1.44^{\mathrm{b}, \mathrm{c}}$ & $+0.21^{\mathrm{b}, \mathrm{c}}$ & \\
$\mathbf{X X}$ & $+1.39^{\mathrm{b}, \mathrm{c}}$ & $+0.53^{\mathrm{b}, \mathrm{c}}$ & \\
\hline
\end{tabular}

${ }^{\mathrm{a}} E / \mathrm{V} v s . \mathrm{SCE}, 0.1 \mathrm{M} \mathrm{Bu}_{4} \mathrm{NBF}_{4}, \mathrm{Pt}$ electrode, scan rate $100 \mathrm{mV} / \mathrm{s} ;{ }^{\mathrm{b}}$ Two-electron process;

${ }^{\mathrm{c}}$ Irreversible wave, values are calculated. as $E^{\mathrm{ox}}=E_{\text {peak }}-0.03$ and $E^{\text {red }}=E_{\text {peak }}+0.03$. 
Figure 3. Cyclic voltammogram of DHP $1 \mathrm{NO}\left(10^{-3} \mathrm{M}\right)$ in $\mathrm{CH}_{2} \mathrm{Cl}_{2}(E / \mathrm{V}$ vs. SCE $0.1 \mathrm{M}$ $\mathrm{Bu}_{4} \mathrm{NBF}_{4}, \mathrm{Pt}$ electrode, scan rate $500 \mathrm{mV} \mathrm{s}{ }^{-1}$ ). The reduction peaks are absent when the voltammogram is first scanned cathodically. As shown by the dotted line, the first reduction wave at $+0.07 \mathrm{~V}$ is reversible when the scanning is reversed at $-0.10 \mathrm{~V}$.

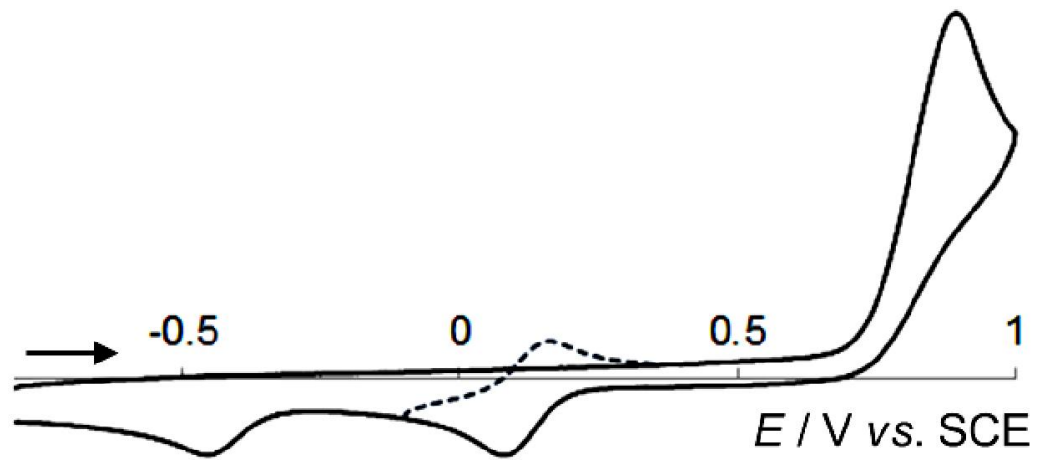

Independent measurements of $\mathbf{2} \mathbf{N O}^{2+}$ and $\mathbf{2} \mathbf{N} \mathbf{X}^{2+}$ confirmed that the two cathodic peaks are due to two-stage 1e-reduction processes of the unsymmetric dications. The first process is completely reversible, and corresponds to the reduction of bis(4-methoxyphenyl)methylium in $\mathbf{2} \mathbf{N O}^{2+}$ or the xanthenylium moiety in $\mathbf{2} \mathbf{N} \mathbf{X}^{2+}$. Furthermore, after scanning of the irreversible second 1e-reduction wave of $2 \mathrm{NO}^{2+}$ and $\mathbf{2} \mathbf{N X}^{2+}$, the anodic peak due to the oxidation of $\mathbf{1 N O}$ or $\mathbf{1 N X}$ appears in the far anodic region of the voltammograms. Such redox properties can only be accounted for by assuming the reaction mechanism shown in Scheme 1, where the elongated C9-C10 bond in DHP is cleaved after just $1 \mathrm{e}$ oxidation of $\mathbf{1} \mathbf{N O}$ to $\mathbf{1 N O}^{+\cdot}$ [33] whereas two-fold 1e-reduction of $\mathbf{2 N O}^{2+}$ to $\mathbf{2} \mathbf{N O}^{*}$ is necessary before the ring closure. $\mathbf{2 N O}^{+\cdot}$ produced from $\mathbf{1 N O}^{+\cdot}$ is more easily oxidized than $\mathbf{1 N O}$ $\left[E^{\text {ox }}(\mathbf{1 N O})=+0.83 \mathrm{~V} ; E^{\text {ox }}\left(\mathbf{2} \mathbf{N O}^{+\bullet}\right)=E_{1}{ }^{\text {red }}\left(\mathbf{2 N O}^{2+}\right)=+0.10 \mathrm{~V}\right]$, and thus the steady-state concentration of $\mathbf{2 N O}^{+\bullet}$ is negligible during the electrochemical oxidation of $\mathbf{1 N O}$, although the same specimen is a long-lived intermediate in the reduction of $2 \mathrm{NO}^{2+}$ due to suppression of disproportionation. The same is true for another series of compounds, $\mathbf{1} \mathbf{N X}^{+\bullet} / \mathbf{1} \mathbf{N} \mathbf{X}^{+\bullet} / \mathbf{2} \mathbf{N} \mathbf{X}^{+\bullet} / \mathbf{2} \mathbf{N} \mathbf{X}^{2+}\left[E^{\text {ox }}(\mathbf{1 N X})=+0.76 \mathrm{~V}\right.$; $E^{\text {ox }}\left(\mathbf{2} \mathbf{N X} \mathbf{X}^{+\bullet}=E_{1}{ }^{\text {red }}\left(\mathbf{2} \mathbf{N X}^{2+}\right)=+0.24 \mathrm{~V} ; E_{2}{ }^{\text {red }}\left(\mathbf{2} \mathbf{N} \mathbf{X}^{2+}\right)=-0.19 \mathrm{~V}\right]$. Thanks to the hysteretic interconversion in redox reactions, unique tricolor electrochromic systems could be constructed using the present unsymmetric derivatives, as shown below.

\subsection{Hysteretic Tricolor Electrochromicity of Unsymmetrically Substituted Redox Pairs}

Upon the electrochemical oxidation of colorless $1 \mathrm{NO}$ in $\mathrm{CH}_{2} \mathrm{Cl}_{2}$, both the blue and red chromophores grow simultaneously to develop a violet color for $\mathbf{2} \mathbf{N O}^{2+}$ (Figure 4(a), isosbestic point at $310 \mathrm{~nm}$ ). On the other hand, the red chromophore predominantly disappears in the first stage of the electrochemical reduction of $\mathbf{2 N O}^{2+}$ (Figure $4(\mathrm{~b}), 295 \mathrm{~nm}$ ), and the blue cation radical $\mathbf{2} \mathbf{N O}^{+\boldsymbol{\bullet}}$ is then converted to colorless 1 NO (Figure 4(c), $290 \mathrm{~nm}$ ) even under constant-current electrolytic conditions (Scheme 5). A similar behavior, but with different colors, was observed for the xanthene derivative. Thus, colorless donor $\mathbf{1 N X}$ was transformed directly into green $\mathbf{2} \mathbf{N} \mathbf{X}^{2+}$ (isosbestic point: $309 \mathrm{~nm}$ ), whereas reduction is a two-stage process; i.e., green $\mathbf{2} \mathbf{N} \mathbf{X}^{2+}$ changes to blue $\mathbf{2} \mathbf{N} \mathbf{X}^{+\bullet}(248,270,300 \mathrm{~nm})$ and blue $\mathbf{2} \mathbf{N X}^{+\bullet}$ changes to colorless $\mathbf{1 N X}(296 \mathrm{~nm})$, which shows the generality of the unique pattern of the color change. 
Figure 4. Changes in the UV-VIS spectra of (a) $1 \mathrm{NO}\left(3.5 \mathrm{~mL} ; 3.0 \times 10^{-5} \mathrm{M}\right.$ in $\mathrm{CH}_{2} \mathrm{Cl}_{2}$ containing $\left.0.05 \mathrm{M} \mathrm{Bu}_{4} \mathrm{NBF}_{4}\right)$ upon electrochemical oxidation $(10 \mu \mathrm{A})$ at 5-min intervals, and $2 \mathrm{NO}^{2+}\left(3.5 \mathrm{~mL}\right.$ soln; $6.2 \times 10^{-6} \mathrm{M}$ in $\mathrm{CH}_{2} \mathrm{Cl}_{2}$ containing $0.05 \mathrm{M} \mathrm{Bu}_{4} \mathrm{NBF}_{4}$ ) upon electrochemical reduction $(40 \mu \mathrm{A})$ : (b) stage 1, at 2-min intervals; (c) stage 2, at 8 -min intervals.
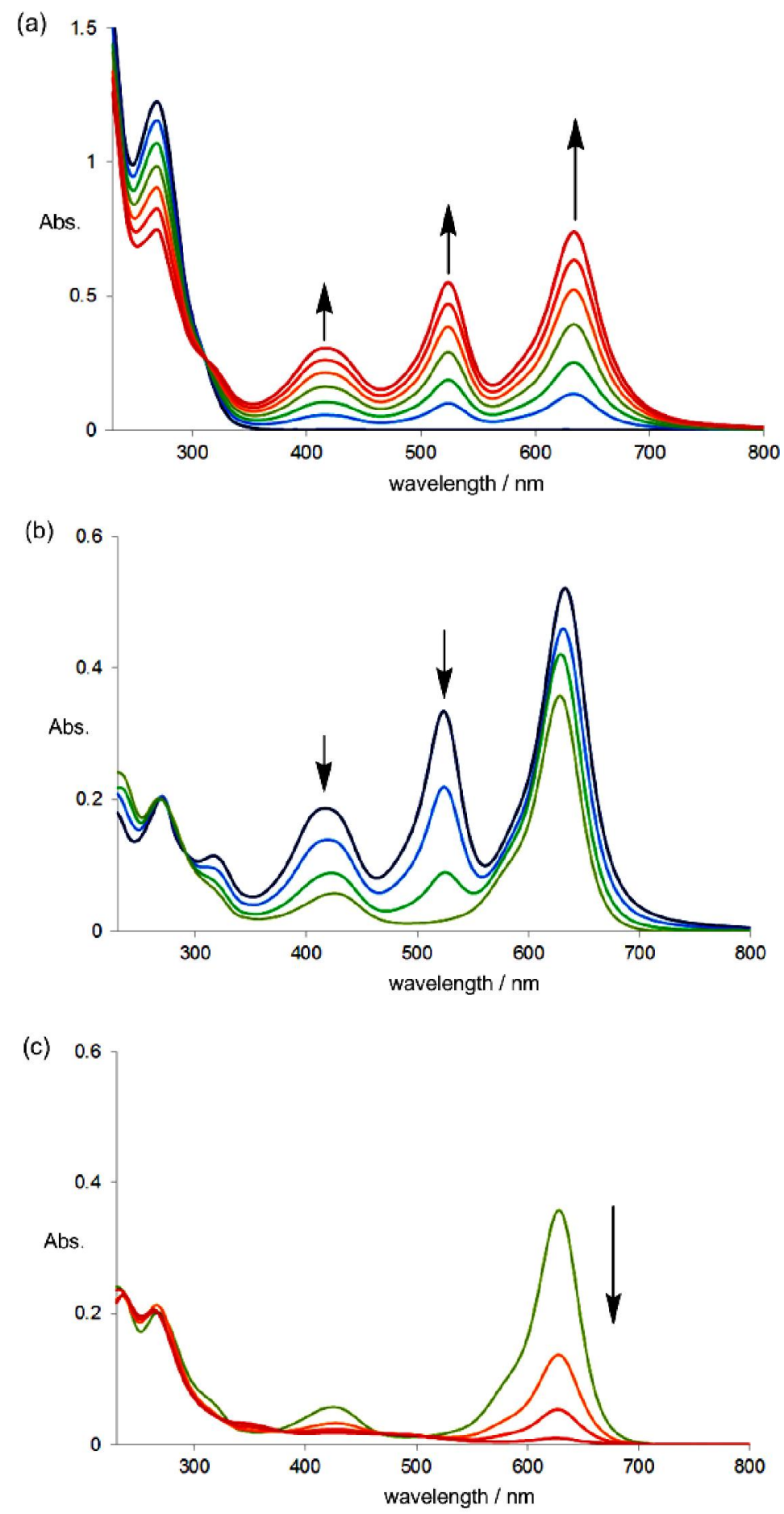
Scheme 5. Hysteretic color changes in the novel tricolor chromic systems.

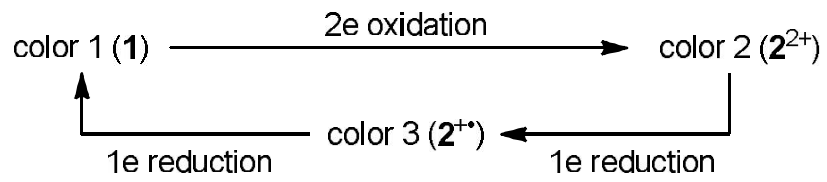

\section{Conclusions}

Compared with the successful examples based on the polymeric materials [34-46], tricolor electrochromicity based on discrete molecules is rare, for which only a limited number of examples have been reported [47-51]. Even among successful examples, a hysteretic pattern for the color change, where there is a difference between oxidation [color $1 \rightarrow$ color 2] and reduction [color $2 \rightarrow$ color $3 \rightarrow$ color 1], is quite unique for the present systems. This novel chromicity is attained by the incorporation of biphenyldiyl-type cation radical $\mathbf{2}^{+\cdot}$ as an additional component to DHP $\mathbf{1}$ and dication $\mathbf{2}^{2+}$. The key to extending the lifetime of $\mathbf{2}^{+\bullet}$ is the different electron-donating properties of two dye chromophores, whose precursors were prepared very efficiently using the flow microreactor method.

We are now developing a new series of tricolor chromic system, which also afford chiroptical properties (e.g., circular dichroism (CD)) as an additional signal, to construct the multi-output response systems (Scheme 6) [3,4,7,52-54]. While the triarylmethyliums attached with chiral substituents only exhibit very small ellipticity to be used as an output signal $(|\Delta \varepsilon|<1.5)$, huge enhancement $(|\Delta \varepsilon|>100)$ could be realized by intramolecular transfer of the point chirality to the axial chirality in the biphenyl-diyl dications $\mathbf{2}^{2+}$ (Scheme 7) [54], in which the two triarylmethylium units are suitably arranged for effective exciton coupling [52,53]. Studies along this vein are now in progress and the results will be reported in due course.

Scheme 6. Multi-output response based on the novel tricolor chromic systems.

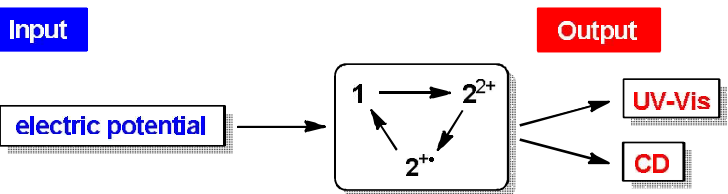

Scheme 7. Interconversion of the enantiomers of axially chiral dications $\mathbf{2}^{2+}$ by rotation to give a diasteromerically biased mixture due to the transfer of point chirality to axial chirality.

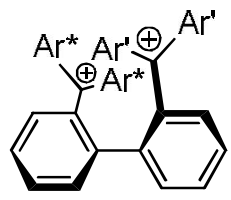

(S) $-2^{2+}$

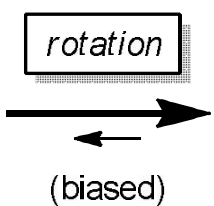

(biased)

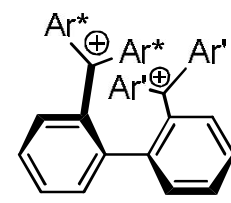

$(R)-2^{2+}$

$\left(A r^{*}=\right.$ electron-donating aryl group with a point chirality) 


\section{Experimental Section}

\subsection{Preparation of 9,9-Bis(4-Dimethylaminophenyl)-10,10-Bis(4-Methoxyphenyl)-9, 10-} Dihydrophenanthrene $1 \mathrm{NO}$

To a suspension of dication salt of $\mathbf{2} \mathrm{NO}^{2+}\left(\mathrm{BF}_{4}{ }^{-}\right)_{2}(104 \mathrm{mg}, 0.129 \mathrm{mmol})$ in THF $(10 \mathrm{~mL})$ was added triethylamine $(3 \mathrm{~mL})$ followed by $\mathrm{SmI}_{2}\left(0.1 \mathrm{~mol} \mathrm{dm}^{-3}\right.$ in THF, $\left.5.0 \mathrm{~mL}, 0.50 \mathrm{mmol}\right)$ over $10 \mathrm{~min}$ at rt. The violet suspension gradually turned to ocher, and then the blue color of $\mathrm{SmI}_{2}$ remained persistent during the addition. After stirring for $1 \mathrm{~h}$ and removal of THF and amine, the residue was suspended in water and extracted with benzene. The organic layer was washed with water and brine, and dried over $\mathrm{K}_{2} \mathrm{CO}_{3}$. Evaporation of solvent followed by chromatographic separation $\left(\mathrm{Al}_{2} \mathrm{O}_{3}\right.$, benzene) gave DHP 1NO as a colorless solid (79 mg, y. 97\%).

Mp 284.5-285.5 ${ }^{\circ} \mathrm{C}$ (decomp.); ${ }^{1} \mathrm{H}$ NMR (400 $\left.\mathrm{MHz} \mathrm{CDCl}_{3}, 0{ }^{\circ} \mathrm{C}\right) \delta / \mathrm{ppm} 7.65-7.71$ (2H, m), 7.18-7.25 (2H, m), 7.08-7.18 (4H, m), 6.80-7.06 (8H, m), 6.43-6.55 (4H, AA'XX'), 6.26-6.38 (4H, AA'XX'), 3.71 (6H, s), 2.85 (12H, s); IR (KBr) 2948, 2832, 1610, 1510, 1444, 1354, 1292, 1252, 1186, 1036, 950, 806, 746, $580 \mathrm{~cm}^{-1}$; FD-MS m/z $630\left(\mathrm{M}^{+}\right.$, BP); Anal. Calcd. for $\mathrm{C}_{44} \mathrm{H}_{42} \mathrm{~N}_{2} \mathrm{O}_{2}$ : C, 83.78; H, 6.71; N, 4.44. Found: C, 83.72; H, 6.88; N, 4.48.

\subsection{Preparation of Spiro[10,10-Bis(4-Dimethylaminophenyl)-9,10-Dihydrophenanthrene-9,9'- [9H]Xanthene] 1NX}

To a suspension of $\mathbf{2} \mathrm{NX}^{2+}\left(\mathrm{BF}_{4}{ }^{-}\right)_{2}(30 \mathrm{mg}, 39.6 \mu \mathrm{mol})$ in THF $(10 \mathrm{~mL})$ was added $\mathrm{SmI}_{2}\left(0.1 \mathrm{~mol} \mathrm{dm}^{-3}\right.$ in THF, $1.7 \mathrm{~mL}, 0.17 \mathrm{mmol}$ ) over $5 \mathrm{~min}$ at $\mathrm{rt}$. The deep green suspension gradually turned to colorless during the addition. After stirring for $30 \mathrm{~min}$ and evaporation of THF, the residue was suspended in water and extracted with $\mathrm{CH}_{2} \mathrm{Cl}_{2}$. The organic layer was washed with water and brine, and dried over $\mathrm{Na}_{2} \mathrm{SO}_{4}$. Evaporation of solvent followed by separation by preparative TLC $\left(\mathrm{SiO}_{2}\right.$, hexane/AcOEt $\left.=4\right)$ gave DHP 1NX as a colorless solid (18 mg, y. 78\%). Single crystalline specimen of $\mathbf{1 N X}$ was obtained by recrystallization from ether.

Mp 294-295 ${ }^{\circ} \mathrm{C}$ (decomp); ${ }^{1} \mathrm{H}$ NMR (400 MHz, $\left.\mathrm{CDCl}_{3}, 24{ }^{\circ} \mathrm{C}\right) \delta / \mathrm{ppm} 8.03(1 \mathrm{H}, \mathrm{d}, \mathrm{J}=7.8 \mathrm{~Hz}), 7.90$ $(1 \mathrm{H}, \mathrm{d}, \mathrm{J}=7.8 \mathrm{~Hz}), 7.46(1 \mathrm{H}, \mathrm{ddd}, \mathrm{J}=7.8,7.8,1.5 \mathrm{~Hz}), 7.34(1 \mathrm{H}, \mathrm{dd}, \mathrm{J}=7.8,1.5 \mathrm{~Hz}), 7.22-7.30$ $(3 \mathrm{H}, \mathrm{m}), 7.13-7.19(2 \mathrm{H}, \mathrm{m}), 6.88-7.05(3 \mathrm{H}, \mathrm{m}), 6.63-6.72(6 \mathrm{H}, \mathrm{m}), 6.61(2 \mathrm{H}, \mathrm{dd}, \mathrm{J}=7.8,1.5 \mathrm{~Hz})$, 6.24 (4H, AA'XX'), 2.84 (12H, s); IR (KBr) 2796, 1610, 1518, 1480, 1440, 1354, 1312, 1244, 950, 808, $750 \mathrm{~cm}^{-1}$; FD-MS m/z $584\left(\mathrm{M}^{+}\right.$, BP); Anal. Calcd. for $\mathrm{C}_{42} \mathrm{H}_{36} \mathrm{~N}_{2} \mathrm{O}: \mathrm{C}, 86.27 ; \mathrm{H}, 6.21$; N, 4.79. Found: C, 86.04; H, 6.41; N, 4.65 .

\subsection{Preparation of Biphenyl-2-yl[Bis(4-Dimethylaminophenyl)Methylium]-2'-yl[Bis(4'-} Methoxyphenyl)Methylium] Bis(Tetrafluoroborate) $2 \mathrm{NO}^{2+}\left(\mathrm{BF}_{4}^{-}\right)_{2}$

To a solution of diol 3NO (117 mg, $0.176 \mathrm{mmol})$ in DME (3 $\mathrm{mL})$ was added propionic anhydride $(0.6 \mathrm{~mL})$ followed by $42 \% \mathrm{HBF}_{4}(6.70 \mathrm{M}, 90 \mu \mathrm{L}, 0.60 \mathrm{mmol})$, and the mixture was heated at $80{ }^{\circ} \mathrm{C}$ for $1 \mathrm{~h}$. By slow cooling to rt, dication salt $\mathbf{2 N O}^{2+}\left(\mathrm{BF}_{4}{ }^{-}\right)_{2}$ was separated as a deep-violet solid (129 mg, y. 91\%), which was filtered, washed with DME and dried in vacuo. 
Mp 194-198 ${ }^{\circ} \mathrm{C}$ (decomp.); ${ }^{1} \mathrm{H}$ NMR (400 MHz, $\left.\mathrm{CD}_{3} \mathrm{CN}, 20{ }^{\circ} \mathrm{C}\right) \delta / \mathrm{ppm} 7.00-7.70$ (16H, m), 6.92-6.98 (4H, AA'XX'), 6.62-6.73 (4H, AA'XX'), 4.03 (3H, s), 4.02 (3H, s), 3.22 (6H, s), 3.17 $(6 \mathrm{H}, \mathrm{s})$; IR (KBr) 1580, 1506, 1464, 1372, 1278, 1220, 1160, 1124, 1084, 1062, 938, 912, 838, $722 \mathrm{~cm}^{-1}$; FAB-MS m/z $630\left(\mathrm{M}^{+}\right.$, BP); Anal. Calcd. for $\mathrm{C}_{44} \mathrm{H}_{42} \mathrm{~N}_{2} \mathrm{O}_{2} \mathrm{~B}_{2} \mathrm{~F}_{8}+0.5 \mathrm{H}_{2} \mathrm{O}: \mathrm{C}, 64.96$; H, 5.33; N, 3.44. Found: C, 65.06; H, 5.40; N, 3.40.

\subsection{Preparation of Biphenyl-2-yl[Bis(4-Dimethylaminophenyl)Methylium]-2'-yl[9-Xanthenylium] Bis(Tetrafluoroborate) $2 \mathrm{NX}^{2+}\left(\mathrm{BF}_{4}{ }^{-}\right)_{2}$}

To a solution of diol $\mathbf{3 N X}(70 \mathrm{mg}, 11.3 \mu \mathrm{mol})$ in DME $(3 \mathrm{~mL})$ was added propionic anhydride $(0.5 \mathrm{~mL})$ followed by $42 \% \mathrm{HBF}_{4}(50 \mu \mathrm{L}, 33.5 \mu \mathrm{mol})$, and the mixture was heated at $80{ }^{\circ} \mathrm{C}$ for $1 \mathrm{~h}$. By slow cooling to rt, dication salt $\mathbf{2} \mathbf{N X}^{2+}\left(\mathrm{BF}_{4}{ }^{-}\right)_{2}$ was separated as a deep-green solid (80 mg, y. 93\%), which was filtered, washed with DME, and dried in vacuo.

Mp 219-220 ${ }^{\circ} \mathrm{C}$ (decomp.); ${ }^{1} \mathrm{H}$ NMR (400 MHz, $\left.\mathrm{CD}_{3} \mathrm{CN}, 50{ }^{\circ} \mathrm{C}\right) \delta / \mathrm{ppm} 8.40(2 \mathrm{H}$, br.), $8.23(2 \mathrm{H}$, br. d, J = 8.5 Hz), $7.90(2 \mathrm{H}$, br. d, J = 8.5 Hz), 7.78-7.84 (3H, br. m), 7.46-7.56 (3H, br. m), 7.32 (2H, ddd, $\mathrm{J}=7.8,7.8,1.0 \mathrm{~Hz}$ ), 7.26-7.30 (1H, br. m), 6.85 (2H, br. d, J = 7.8 Hz), 6.20-7.20 (7H, br.), 3.30 (6H, br. s), 3.29 (6H, br. s); IR (KBr) 1622, 1584, 1506, 1374, 1174, 1084, 1036, 910, 762, $722 \mathrm{~cm}^{-1}$; FAB-MS $m / z 584\left(\mathrm{M}^{+}\right.$, BP); Anal. Calcd. for $\mathrm{C}_{42} \mathrm{H}_{36} \mathrm{~N}_{2} \mathrm{OB}_{2} \mathrm{~F}_{8}: \mathrm{C}, 66.52 ; \mathrm{H}, 4.78 ; \mathrm{N}, 3.69$. Found: C, 66.64; H, 4.79; N, 3.76 .

\subsection{Oxidation to Biphenyl-2-yl[Bis(4-Dimethylaminophenyl)Methylium]-2'-yl[Bis(4'-} Methoxyphenyl)Methylium] Bis(Hexachloroantimonate) $\mathbf{2} \mathrm{NO}^{2+}\left(\mathrm{SbCl}_{6}^{-}\right)_{2}$

To a solution of DHP $\mathbf{1 N O}(10 \mathrm{mg}, 15.9 \mu \mathrm{mol})$ in $\mathrm{CH}_{2} \mathrm{Cl}_{2}(10 \mathrm{~mL})$ was added (4- $\left.\mathrm{BrC}_{6} \mathrm{H}_{4}\right)_{3} \mathrm{~N}^{+\bullet} \mathrm{SbCl}_{6}^{-}(26 \mathrm{mg}, 31.8 \mu \mathrm{mol})$, and mixture was stirred for $20 \mathrm{~min}$ at rt. Deep-violet precipitates of $2 \mathrm{NO}^{2+}\left(\mathrm{SbCl}_{6}{ }^{-}\right)_{2}(17 \mathrm{mg}$, y. $82 \%)$ were separated upon dilution with hexane $(1 \mathrm{~mL})$, which were filtered, washed with $\mathrm{CH}_{2} \mathrm{Cl}_{2}$ and dried in vacuo.

$\mathrm{Mp}>310{ }^{\circ} \mathrm{C}$ (decomp.); IR (KBr) 1580, 1438, 1372, 1280, 1160, 1004, 938, 912, 832, 722, $578 \mathrm{~cm}^{-1}$; Anal. Calcd. for $\mathrm{C}_{44} \mathrm{H}_{42} \mathrm{~N}_{2} \mathrm{O}_{2} \mathrm{Sb}_{2} \mathrm{Cl}_{12}$ : C, 40.66; H, 3.26; N, 2.16. Found: C, 40.76; H, 3.29; N, 2.26 .

\subsection{Oxidation to Biphenyl-2-yl[Bis(4-Dimethylaminophenyl)Methylium]-2'-yl[9-Xanthenylium]} Bis(Hexachloroantimonate) $\mathbf{2} \mathrm{NX}^{2+}\left(\mathrm{SbCl}_{6}^{-}\right)_{2}$

To a solution of DHP $\mathbf{1 N X}(5.0 \mathrm{mg}, 8.6 \mu \mathrm{mol})$ in $\mathrm{CH}_{2} \mathrm{Cl}_{2}(2.5 \mu \mathrm{mL})$ was added (4- $\left.\mathrm{BrC}_{6} \mathrm{H}_{4}\right)_{3} \mathrm{~N}^{+\bullet} \mathrm{SbCl}_{6}^{-}(14 \mathrm{mg}, 17 \mu \mathrm{mol})$, and mixture was stirred for $10 \mathrm{~min}$ at rt. Deep-green precipitates of $2 \mathrm{NX}^{2+}\left(\mathrm{SbCl}_{6}{ }^{-}\right)_{2}(8.5 \mathrm{mg}, \mathrm{y} .79 \%)$ were separated upon dilution with hexane $(1 \mathrm{~mL})$, which were filtered, washed with $\mathrm{CH}_{2} \mathrm{Cl}_{2}$ and dried in vacuo.

Mp 203-210 ${ }^{\circ} \mathrm{C}$ (decomp.); IR (KBr) 1620, 1582, 1504, 1476, 1372, 1168, 940, 910, 832, 754, $722 \mathrm{~cm}^{-1}$; Anal. Calcd. for $\mathrm{C}_{42} \mathrm{H}_{36} \mathrm{~N}_{2} \mathrm{OSb}_{2} \mathrm{Cl}_{12}$ : C, 40.17; H, 2.89; N, 2.23. Found: C, 39.90; H, 3.05; N, 2.07 . 


\subsection{Preparation of 2-[Bis(4-Dimethylaminophenyl)Hydroxymethyl]-2'-[Bis(4'-} Methoxylphenyl)Hydroxymethyl]Biphenyl 3 NO via Flow Microreactor Method

An integrated flow microreactor system consisting of four T-shaped micromixers (M1, M2, M3, and M4), four microtube reactors (R1, R2, R3, and R4), and five microtube units [P1 (inner diameter $\phi=1000 \mu \mathrm{m}$, length $l=100 \mathrm{~cm}), \mathrm{P} 2(\phi=1000 \mu \mathrm{m}, l=50 \mathrm{~cm}), \mathrm{P} 3(\phi=1000 \mu \mathrm{m}, l=100 \mathrm{~cm}), \mathrm{P} 4$ $(\phi=1000 \mu \mathrm{m}, l=50 \mathrm{~cm})$, and P5 $(\phi=1000 \mu \mathrm{m}, l=100 \mathrm{~cm})]$ was used. The whole flow microreactor system was dipped in a water bath $\left(24{ }^{\circ} \mathrm{C}\right.$ ). A solution of 2,2'-dibromobiphenyl $(0.10 \mathrm{M})$ in THF (flow rate $\left.=6.00 \mathrm{~mL} \mathrm{~min}^{-1}\right)$ and a solution of $\operatorname{BuLi}(0.50 \mathrm{M})$ in hexane (flow rate $=1.20 \mathrm{~mL} \mathrm{~min}{ }^{-1}$ ) were introduced to M1 $(\phi=250 \mu \mathrm{m})$. The resulting solution was passed through $\mathrm{R} 1 \quad(\phi=500 \mu \mathrm{m}$, $l=3.5 \mathrm{~cm}$ ) and was mixed with a solution of 4,4'-dimethoxybenzophenone $40(0.20 \mathrm{M})$ in THF (flow

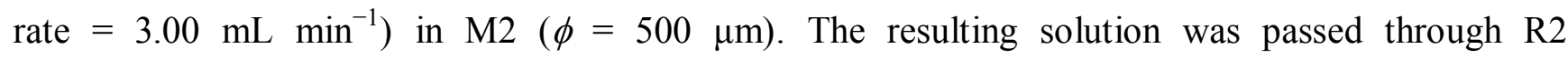
$(\phi=1000 \mu \mathrm{m}, l=50 \mathrm{~cm})$ and was introduced to $\mathrm{M} 3(\phi=500 \mu \mathrm{m})$ where the solution was mixed with a solution of $\operatorname{BuLi}(0.50 \mathrm{M})$ in hexane (flow rate $=1.44 \mathrm{~mL} \mathrm{~min}{ }^{-1}$ ). The resulting solution was passed through R3 ( $\phi=1000 \mu \mathrm{m}, l=200 \mathrm{~cm})$ and was introduced to $\mathrm{M} 4(\phi=500 \mu \mathrm{m})$ where the solution was

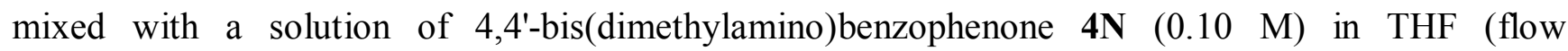
rate $\left.=7.20 \mathrm{~mL} \mathrm{~min}^{-1}\right)$. The resulting solution was passed through $\mathrm{R} 4(\phi=1000 \mu \mathrm{m}, l=200 \mathrm{~cm})$. After a steady state was reached, the product solution was collected for $60 \mathrm{~s}$ and was treated with $\mathrm{BuLi}$ $(1.67 \mathrm{M})$ in hexane $(2.0 \mathrm{~mL})$ to consume excess ketones and quench the reaction with water.

After diluted with $\mathrm{H}_{2} \mathrm{O}$, the whole mixture was extracted with $\mathrm{Et}_{2} \mathrm{O}$. The combined organic layers were washed with water and brine, and dried over anhydrous $\mathrm{Na}_{2} \mathrm{SO}_{4}$. After filtration, solvent was concentrated under reduced pressure. The residue was purified by column chromatography on silica gel (hexane/EtOAc $=3$ ) to give $\mathbf{3 N O}(291 \mathrm{mg})$ as a colorless solid in $73 \%$ yield.

Mp 221-222 ${ }^{\circ} \mathrm{C}$ (decomp.); ${ }^{1} \mathrm{H}$ NMR (400 MHz, $\left.\mathrm{CDCl}_{3}, 24{ }^{\circ} \mathrm{C}\right) \delta / \mathrm{ppm} 7.00-7.10$ (9H, m), 6.92-6.96 (2H, br. d, J = 8.8 Hz), 6.74-6.86 (9H, m), 6.61-6.65 (4H, m), $6.19(1 \mathrm{H}, \mathrm{dd}, \mathrm{J}=8.6$, $1.0 \mathrm{~Hz}), 6.04(1 \mathrm{H}, \mathrm{dd}, \mathrm{J}=8.6,1.0 \mathrm{~Hz}), 5.23(1 \mathrm{H}, \mathrm{s}), 3.83(3 \mathrm{H}, \mathrm{s}), 3.78(3 \mathrm{H}, \mathrm{s}) 3.56(1 \mathrm{H}, \mathrm{s}), 2.95$ $(6 \mathrm{H}, \mathrm{s}), 2.91$ (6H, s); IR (KBr) 3550sh, 2900, 2832, 1612, 1512, 1466, 1352, 1298, 1250, 1174, 1062, 826, 762, $560 \mathrm{~cm}^{-1}$; FD-MS $\mathrm{m} / z$ (rel intensity) $664\left(\mathrm{M}^{+}, 100\right), 646$ (3); Anal. Calcd. for $\mathrm{C}_{44} \mathrm{H}_{44} \mathrm{~N}_{2} \mathrm{O}_{4}$ : C, 79.49; H, 6.67; N, 4.21. Found: C, 79.37; H, 6.80; N, 4.05.

\subsection{Preparation of 2-[Bis(4-Dimethylaminophenyl)Hydroxymethyl]-2'-[Bis(4'-}

\section{Methoxylphenyl)Hydroxymethyl]Biphenyl 3NO via Macro Batch Method}

To a colorless solution of 2,2'-diiodobiphenyl (692 $\mathrm{g}, 1.70 \mathrm{mmol})$ in THF $(12 \mathrm{~mL})$ was added dropwise BuLi $\left(1.70 \mathrm{~mol} \mathrm{dm}{ }^{-3}\right.$ in hexane, $\left.2.30 \mathrm{~mL}, 3.91 \mathrm{mmol}\right)$ at $-78{ }^{\circ} \mathrm{C}$ for $5 \mathrm{~min}$ under $\mathrm{Ar}$, and the mixture was stirred for $45 \mathrm{~min}$ at this temperature. To the resultant suspension of 2,2'-dilithiobiphenyl was added a mixture of 4,4'-bis(dimethylamino)benzophenone 4N (406 mg, $1.51 \mathrm{mmol}$ ) and 4,4'-dimethoxybenzophenone 40 (364 mg, $1.50 \mathrm{mmol})$ in THF (30 mL) for $15 \mathrm{~min}$. After stirring for $4 \mathrm{~h}$, BuLi (1.70 mol dm${ }^{-3}$ in hexane, $1.00 \mathrm{~mL}, 1.70 \mathrm{mmol}$ ) was added for $3 \mathrm{~min}$ to consume excess ketones. The resultant red solution was further stirred for $1 \mathrm{~h}$ and quenched by adding water. THF was evaporated, and the residue was extracted with benzene. The organic layer was washed with water and brine, and dried over $\mathrm{Na}_{2} \mathrm{SO}_{4}$. Evaporation of the solvent gave $1.09 \mathrm{~g}$ of oily material containing 
unsymmetric diol 3NO. Two symmetric diols, 3NN and 300, were also formed in this reaction. Chromatographic separation on $\mathrm{SiO}_{2}$ (hexane/AcOEt $=7 / 3$ ) followed by crystallization from ether gave 3NO as colorless crystals (120 mg, y. 12\%).

\subsection{Preparation of 9-[2'-Bis(4-Dimethylaminophenyl)Hydoroxymethylbiphenyl-2-yl]-9- Hydroxyxanthene $\mathbf{3 N X}$ via Flow Microreactor Method}

An integrated flow microreactor system consisting of four T-shaped micromixers (M1, M2, M3, and M4), four microtube reactors (R1, R2, R3, and R4), and five microtube units [P1 (inner diameter $\phi=1000 \mu \mathrm{m}$, length $l=100 \mathrm{~cm}), \mathrm{P} 2(\phi=1000 \mu \mathrm{m}, l=50 \mathrm{~cm}), \mathrm{P} 3(\phi=1000 \mu \mathrm{m}, l=100 \mathrm{~cm}), \mathrm{P} 4$ $(\phi=1000 \mu \mathrm{m}, l=50 \mathrm{~cm})$, and P5 $(\phi=1000 \mu \mathrm{m}, l=100 \mathrm{~cm})]$ was used. The whole flow microreactor system was dipped in a water bath $\left(24^{\circ} \mathrm{C}\right)$. A solution of 2,2'-dibromobiphenyl $(0.10 \mathrm{M})$ in THF (flow rate $\left.=6.00 \mathrm{~mL} \mathrm{~min}^{-1}\right)$ and a solution of $\operatorname{BuLi}(0.50 \mathrm{M})$ in hexane (flow rate $=1.20 \mathrm{~mL} \mathrm{~min}{ }^{-1}$ ) were introduced to $\mathrm{M} 1(\phi=250 \mu \mathrm{m})$. The resulting solution was passed through $\mathrm{R} 1(\phi=500 \mu \mathrm{m}, l=3.5$ $\mathrm{cm}$ ) and was mixed with a solution of xanthone $4 \mathbf{X}(0.20 \mathrm{M})$ in THF (flow rate $=3.00 \mathrm{~mL} \mathrm{~min}^{-1}$ ) in $\mathrm{M} 2(\phi=500 \mu \mathrm{m})$. The resulting solution was passed through $\mathrm{R} 2(\phi=1000 \mu \mathrm{m}, l=50 \mathrm{~cm})$ and was introduced to M3 $(\phi=500 \mu \mathrm{m})$ where the solution was mixed with a solution of BuLi $(0.50 \mathrm{M})$ in hexane (flow rate $=1.44 \mathrm{~mL} \mathrm{m^{-1 }}$ ). The resulting solution was passed through $\mathrm{R} 3(\phi=1000 \mu \mathrm{m}$, $l=200 \mathrm{~cm})$ and was introduced to M4 $(\phi=500 \mu \mathrm{m})$ where the solution was mixed with a solution of 4,4'-bis(dimethylamino)benzophenone $4 \mathbf{N}(0.10 \mathrm{M})$ in THF (flow rate $=7.20 \mathrm{~mL} \mathrm{~min}^{-1}$ ). The resulting solution was passed through $\mathrm{R} 4(\phi=1000 \mu \mathrm{m}, l=200 \mathrm{~cm})$. After a steady state was reached, the product solution was collected for $60 \mathrm{~s}$ and was treated with $\mathrm{BuLi}(1.67 \mathrm{M})$ in hexane $(2.0 \mathrm{~mL})$ to consume excess ketones and quench the reaction with water. After diluted with $\mathrm{H}_{2} \mathrm{O}$, the whole mixture was extracted with $\mathrm{Et}_{2} \mathrm{O}$. The combined organic layers were washed with water and brine, and dried over anhydrous $\mathrm{Na}_{2} \mathrm{SO}_{4}$. After filtration, solvent was concentrated under reduced pressure. The residue was purified by column chromatography on silica gel (hexane/EtOAc $=5$ ) to give $\mathbf{3 N X}$ (227 mg) as a colorless solid in 61\% yield.

Mp 143-152 ${ }^{\circ} \mathrm{C}$ (decomp.); ${ }^{1} \mathrm{H}$ NMR (400 MHz, $\left.\mathrm{CDCl}_{3}, 24{ }^{\circ} \mathrm{C}\right) \delta / \mathrm{ppm} 7.63(1 \mathrm{H}, \mathrm{dd}, \mathrm{J}=7.8$, $1.5 \mathrm{~Hz}), 7.39(1 \mathrm{H}, \mathrm{dd}, \mathrm{J}=7.8,1.5 \mathrm{~Hz}), 7.32(1 \mathrm{H}, \mathrm{ddd}, \mathrm{J}=7.8,7.8,1.5 \mathrm{~Hz}), 7.09-7.24(6 \mathrm{H}, \mathrm{m}), 7.02$ (2H, AA'XX'), 6.95-7.00 (2H, m), 6.87 (2H, AA'XX'), 6.83-6.93 (3H, m), $6.72(1 \mathrm{H}, \mathrm{ddd}, \mathrm{J}=7.8$, 7.8, $1.5 \mathrm{~Hz}), 6.64$ (2H, AA'XX'), 6.59 (2H, AA'XX'), $6.18(1 \mathrm{H}, \mathrm{dd}, \mathrm{J}=7.8,1.5 \mathrm{~Hz}), 5.72(1 \mathrm{H}, \mathrm{m})$, $3.02(1 \mathrm{H}, \mathrm{s}), 2.94(6 \mathrm{H}, \mathrm{s}), 2.93(6 \mathrm{H}, \mathrm{s})$; IR (KBr) 3048, 2796, 1612, 1520, 1478, 1450, 1354, 1240, 1190, 1154, 1032, 948, 816, $758 \mathrm{~cm}^{-1}$; FD-MS m/z $618\left(\mathrm{M}^{+}, 100\right)$; Anal. Calcd. for $\mathrm{C}_{42} \mathrm{H}_{38} \mathrm{~N}_{2} \mathrm{O}_{3}$ : C, 81.53; H, 6.19; N, 4.53. Found: C, 81.60; H, 6.19; N, 4.40.

\subsection{Preparation of 9-[2'-Bis(4-Dimethylaminophenyl)Hydoroxymethylbiphenyl-2-yl]-9-} Hydroxyxanthene $\mathbf{3 N X}$ via Macro Batch Method

To a colorless solution of 2,2'-diiodobiphenyl (2.04 g, $5.02 \mathrm{mmol})$ in THF $(20 \mathrm{~mL})$ was added dropwise BuLi $\left(1.47 \mathrm{~mol} \mathrm{dm}^{-3}\right.$ in hexane, $\left.7.10 \mathrm{~mL}, 10.4 \mathrm{mmol}\right)$ at $0{ }^{\circ} \mathrm{C}$ under $\mathrm{Ar}$, and the mixture was stirred for $10 \mathrm{~min}$ at this temperature. To the resultant suspension of 2,2'-dilithiobiphenyl was added a mixture of 4,4'-bis(dimethylamino)benzophenone $4 \mathbf{N}(1.30 \mathrm{~g}, 4.85 \mathrm{mmol})$ and xanthone $4 \mathbf{X}(971 \mathrm{mg}$, $4.95 \mathrm{mmol})$ in THF $(90 \mathrm{~mL})$. After stirring for $2 \mathrm{~h}$ at $\mathrm{rt}$, the reaction was quenched by adding water. 
THF was evaporated, and the residue was extracted with benzene. The organic layer was washed with water and brine, and dried over $\mathrm{Na}_{2} \mathrm{SO}_{4}$. Evaporation of the solvent gave $3.66 \mathrm{~g}$ of oily material containing unsymmetric diol 3NX. Two symmetric diols, $\mathbf{3 N N}$ and $\mathbf{3 X X}$, were also formed in this reaction. Chromatographic separation on $\mathrm{SiO}_{2}$ (AcOEt/hexane, 1/4-1/2) followed by crystallization from $\mathrm{MeOH}$ gave 3NX as colorless crystals (250 mg, y. 8.6\%).

\subsection{Preparation of 2-\{Bis[3,4-Bis(Octyloxy)Phenyl]Hydroxymethyl $\}-2 '-\left[B i s\left(4^{\prime}-\right.\right.$ Methoxylphenyl)Hydroxymethyl]Biphenyl $\mathbf{3 O O}_{8}$}

An integrated flow microreactor system consisting of four T-shaped micromixers (M1, M2, M3, and M4), four microtube reactors (R1, R2, R3, and R4), and five microtube units [P1 (inner diameter $\phi=1000 \mu \mathrm{m}$, length $l=100 \mathrm{~cm}), \mathrm{P} 2(\phi=1000 \mu \mathrm{m}, l=50 \mathrm{~cm}), \mathrm{P} 3(\phi=1000 \mu \mathrm{m}, l=100 \mathrm{~cm}), \mathrm{P} 4$ $(\phi=1000 \mu \mathrm{m}, l=50 \mathrm{~cm})$, and P5 $(\phi=1000 \mu \mathrm{m}, l=100 \mathrm{~cm})]$ was used. The whole flow microreactor system was dipped in a water bath $\left(24^{\circ} \mathrm{C}\right.$ ). A solution of 2,2'-dibromobiphenyl $(0.10 \mathrm{M})$ in THF (flow rate $=6.00 \mathrm{~mL} \mathrm{~min}^{-1}$ ) and a solution of $\operatorname{BuLi}(0.50 \mathrm{M})$ in hexane (flow rate $=1.20 \mathrm{~mL} \mathrm{~min}{ }^{-1}$ ) were introduced to M1 $(\phi=250 \mu \mathrm{m})$. The resulting solution was passed through $\mathrm{R} 1 \quad(\phi=500 \mu \mathrm{m}$, $l=3.5 \mathrm{~cm}$ ) and was mixed with a solution of 4,4'-dimethoxybenzophenone $40(0.20 \mathrm{M})$ in THF (flow rate $\left.=3.00 \mathrm{~mL} \mathrm{~min}^{-1}\right)$ in $\mathrm{M} 2(\phi=500 \mu \mathrm{m})$. The resulting solution was passed through $\mathrm{R} 2(\phi=1000 \mu \mathrm{m}$, $l=50 \mathrm{~cm})$ and was introduced to $\mathrm{M} 3(\phi=500 \mu \mathrm{m})$ where the solution was mixed with a solution of $\operatorname{BuLi}(0.50 \mathrm{M})$ in hexane (flow rate $=1.44 \mathrm{~mL} \mathrm{~min}^{-1}$ ). The resulting solution was passed through $\mathrm{R} 3$ $(\phi=1000 \mu \mathrm{m}, l=200 \mathrm{~cm})$ and was introduced to M4 $(\phi=500 \mu \mathrm{m})$ where the solution was mixed with a solution of 3,3',4,4'-tetrakis(octyloxy)benzophenone $\mathbf{4 O}_{\mathbf{8}}\left(0.10 \mathrm{M}\right.$ ) in THF (flow rate $=7.20 \mathrm{~mL} \mathrm{~min}^{-1}$ ). The resulting solution was passed through $\mathrm{R} 4(\phi=1000 \mu \mathrm{m}, l=200 \mathrm{~cm})$. After a steady state was reached, the product solution was collected for $120 \mathrm{~s}$ and was treated with $\mathrm{H}_{2} \mathrm{O}$ to quench the reaction.

After diluted with $\mathrm{H}_{2} \mathrm{O}$, the whole mixture was extracted with $\mathrm{CH}_{2} \mathrm{Cl}_{2}$. The combined organic layers were washed with water and brine, and dried over anhydrous $\mathrm{Na}_{2} \mathrm{SO}_{4}$. After filtration, solvent was concentrated under reduced pressure. The residue was purified by column chromatography on silica gel $\left(\mathrm{CH}_{2} \mathrm{Cl}_{2} /\right.$ hexane $\left.=3\right)$ to give $\mathbf{3 O O}_{8}(889 \mathrm{mg})$ as a colorless oil in $68 \%$ yield.

${ }^{1} \mathrm{H}$ NMR $\left(300 \mathrm{MHz}, \mathrm{CDCl}_{3}\right) \delta / \mathrm{ppm} 7.11-7.00(6 \mathrm{H}, \mathrm{m}), 6.85-6.72(12 \mathrm{H}, \mathrm{m}), 6.62(1 \mathrm{H}, \mathrm{dd}, J=8.4$, $1.8 \mathrm{~Hz}), 6.52(1 \mathrm{H}, \mathrm{dd}, J=8.4,1.8 \mathrm{~Hz}), 6.14-6.08(2 \mathrm{H}, \mathrm{m}), 4.39(1 \mathrm{H}, \mathrm{s}), 4.19(1 \mathrm{H}, \mathrm{s}), 4.00(2 \mathrm{H}, \mathrm{t}$, $J=6.6 \mathrm{~Hz}), 3.97(2 \mathrm{H}, \mathrm{t}, J=6.6 \mathrm{~Hz}), 3.90-3.74(10 \mathrm{H}, \mathrm{m}), 1.89-1.63(8 \mathrm{H}, \mathrm{m}), 1.53-1.18(40 \mathrm{H}, \mathrm{m})$, 0.94-0.82 (12H, m); ${ }^{13} \mathrm{C}$ NMR (100 MHz, $\left.\mathrm{CDCl}_{3}\right) \delta / \mathrm{ppm} 158.53,158.45,148.35,148.31,148.26$, $147.75,143.94,143.87,141.12,140.88,138.98,138.80,131.58,131.33,130.31,130.18,129.64$, $128.53,125.98,125.93,125.79,121.16,120.34,115.04,113.10,112.97,112.87,112.57,83.35,83.17$, $69.27,69.20,69.12,68.95,55.18,55.15,31.78,29.41,29.35,29.23,29.13,25.98,25.94,22.62,14.05$; IR (neat) 3538, 3397, 3053, 2953, 2927, 2856, 1607, 1583, 1509, 1468, 1442, 1435, 1417, 1379, 1298, 1252, 1175, 1162, 1137, 1064, 1037, 1064, 1037, 828, 808, 789, $756 \mathrm{~cm}^{-1}$; FD-MS m/z $1091\left(\mathrm{M}^{+}, 83\right)$, 1090 (BP); FD-HR-MS (FD) Calcd. for $\mathrm{C}_{72} \mathrm{H}_{98} \mathrm{O}_{8}$ : 1090.7262 Found: 1090.7244. 


\subsection{Preparation of 2-\{Bis[3,4-Bis(Hexadecyloxy)Phenyl]Hydroxymethyl\}-2'-[Bis(4'- Methoxylphenyl)Hydroxymethyl]Biphenyl $\mathbf{3 O O}_{16}$}

An integrated flow microreactor system consisting of four T-shaped micromixers (M1, M2, M3, and M4), four microtube reactors (R1, R2, R3, and R4), and five microtube units [P1 (inner diameter $\phi=1000 \mu \mathrm{m}$, length $l=100 \mathrm{~cm}), \mathrm{P} 2(\phi=1000 \mu \mathrm{m}, l=50 \mathrm{~cm}), \mathrm{P} 3(\phi=1000 \mu \mathrm{m}, l=100 \mathrm{~cm}), \mathrm{P} 4$ $(\phi=1000 \mu \mathrm{m}, l=50 \mathrm{~cm})$, and P5 $(\phi=1000 \mu \mathrm{m}, l=100 \mathrm{~cm})]$ was used. The whole flow microreactor system was dipped in a water bath $\left(24^{\circ} \mathrm{C}\right)$. A solution of 2,2'-dibromobiphenyl $(0.10 \mathrm{M})$ in THF (flow rate $\left.=6.00 \mathrm{~mL} \mathrm{~min}{ }^{-1}\right)$ and a solution of $\operatorname{BuLi}(0.50 \mathrm{M})$ in hexane (flow rate $=1.20 \mathrm{~mL} \mathrm{~min}{ }^{-1}$ ) were introduced to M1 $(\phi=250 \mu \mathrm{m})$. The resulting solution was passed through $\mathrm{R} 1 \quad(\phi=500 \mu \mathrm{m}$, $l=3.5 \mathrm{~cm}$ ) and was mixed with a solution of 4,4'-dimethoxybenzophenone $40(0.20 \mathrm{M})$ in THF (flow

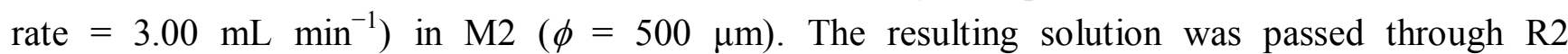
$(\phi=1000 \mu \mathrm{m}, l=50 \mathrm{~cm})$ and was introduced to $\mathrm{M} 3(\phi=500 \mu \mathrm{m})$ where the solution was mixed with a solution of BuLi $(0.50 \mathrm{M})$ in hexane (flow rate $=1.44 \mathrm{~mL} \mathrm{~min}{ }^{-1}$ ). The resulting solution was passed through R3 ( $\phi=1000 \mu \mathrm{m}, l=200 \mathrm{~cm})$ and was introduced to M4 $(\phi=500 \mu \mathrm{m})$ where the solution was mixed with a solution of 3,3',4,4'-tetrakis(hexadecyloxy)benzophenone $\mathbf{4 O}_{\mathbf{1 6}}(0.10 \mathrm{M})$ in toluene (flow rate $\left.=7.20 \mathrm{~mL} \mathrm{~min}^{-1}\right)$. The resulting solution was passed through $\mathrm{R} 4(\phi=1000 \mu \mathrm{m}, l=200 \mathrm{~cm})$. After a steady state was reached, the product solution was collected for $60 \mathrm{~s}$ and was treated with $\mathrm{H}_{2} \mathrm{O}$ to quench the reaction.

After diluted with $\mathrm{H}_{2} \mathrm{O}$, the whole mixture was extracted with $\mathrm{CH}_{2} \mathrm{Cl}_{2}$. The combined organic layers were washed with water and brine, and dried over anhydrous $\mathrm{Na}_{2} \mathrm{SO}_{4}$. After filtration, solvent was concentrated under reduced pressure. The residue was purified by column chromatography on silica gel $\left(\mathrm{CH}_{2} \mathrm{Cl}_{2} /\right.$ hexane $\left.=2\right)$ and GPC separation $(1+2 \mathrm{H})$ to give $\mathbf{3 O O}_{16}(889 \mathrm{mg})$ as a colorless oil in $68 \%$ yield, which was solidified upon standing.

Mp 60-62 ${ }^{\circ} \mathrm{C} ;{ }^{1} \mathrm{H}$ NMR (300 MHz, $\mathrm{CDCl}_{3}$ ) $\delta / \mathrm{ppm} 7.11-6.99(6 \mathrm{H}, \mathrm{m}), 6.85-6.72$ (12H, m), 6.63 $(1 \mathrm{H}, \mathrm{dd}, J=8.4,1.8 \mathrm{~Hz}), 6.52(1 \mathrm{H}, \mathrm{dd}, J=8.4,1.8 \mathrm{~Hz}), 6.14-6.08(2 \mathrm{H}, \mathrm{m}), 4.39(1 \mathrm{H}, \mathrm{s}), 4.19(1 \mathrm{H}, \mathrm{s})$, $4.00(2 \mathrm{H}, \mathrm{t}, J=6.6 \mathrm{~Hz}), 3.96(2 \mathrm{H}, \mathrm{t}, J=6.6 \mathrm{~Hz}), 3.90-3.73(10 \mathrm{H}, \mathrm{m}), 1.89-1.62(8 \mathrm{H}, \mathrm{m}), 1.52-1.18$ (104H, m), 0.92-0.82 (12H, m); ${ }^{13} \mathrm{C}$ NMR (100 MHz, $\left.\mathrm{CDCl}_{3}\right) \delta / \mathrm{ppm} 158.56,158.50,148.40,148.36$, $148.28,147.79,143.97,143.90,141.16,140.91,140.65,139.02,138.85,131.61,131.36,130.34$, $130.21,129.67,128.57,126.02,125.97,125.85,121.20,120.37,115.11,113.15,113.00,112.92$, $112.62,83.38,83.20,69.32,69.25,69.17,69.02,55.23,55.20,31.92,29.71,29.66,29.51,29.46$, 29.37, 29.30, 29.20, 26.06, 26.02, 25.99, 22.68, 14.10; IR (KBr) 3382, 3051, 2919, 2850, 1607, 1510, 1468, 1434, 1416, 1389, 1302, 1254, 1173, 1138, 1064, 1039, 827, 810, 760, 721, $560 \mathrm{~cm}^{-1}$; FD-MS m/z 1540 (BP), 1539 (M+, 82); FD-HR-MS (FD) Calcd. for $\mathrm{C}_{104} \mathrm{H}_{162} \mathrm{O}_{8}: 1539.2270$ Found: 1539.2297.

\subsection{Preparation of 3,3',4,4'-Tetrakis(Octyloxy)Benzophenone $\mathbf{4 O}_{8}$}

To a solution of 4-bromo-1,2-bis(octyloxy)benzene $(4.14 \mathrm{~g}, 10.0 \mathrm{mmol})$ in $50 \mathrm{~mL}$ of dry ether was added BuLi in hexane $(1.57 \mathrm{M}, 6.40 \mathrm{~mL}, 10.0 \mathrm{mmol})$ at $22{ }^{\circ} \mathrm{C}$ under Ar, and the mixture was stirred for $1 \mathrm{~h}$. To the suspension was added $N$-carboethoxypiperidine $(770 \mu \mathrm{L}, 4.99 \mathrm{mmol})$ and the mixture was stirred at $23{ }^{\circ} \mathrm{C}$ for $20 \mathrm{~h}$. After diluted with $3 \mathrm{M} \mathrm{HCl}$ aq., the whole mixture was extracted with $\mathrm{CH}_{2} \mathrm{Cl}_{2}$. The combined organic layers were washed with $3 \mathrm{M} \mathrm{HCl}$ aq. and $1 \mathrm{M} \mathrm{NaOH}$ aq., and dried 
over anhydrous $\mathrm{MgSO}_{4}$. After filtration, solvent was concentrated under reduced pressure. The residue was purified by column chromatography on silica gel $\left(\mathrm{CH}_{2} \mathrm{Cl}_{2} /\right.$ hexane $\left.=2\right)$ to give $\mathbf{4 O}_{\mathbf{8}}(2.92 \mathrm{~g})$ as a colorless solid in $84 \%$ yield.

Mp 58.5-59.5 ${ }^{\circ} \mathrm{C} ;{ }^{1} \mathrm{H}$ NMR $\left(300 \mathrm{MHz}, \mathrm{CDCl}_{3}\right) \delta / \mathrm{ppm} 7.40(2 \mathrm{H}, \mathrm{d}, J=1.8 \mathrm{~Hz}), 7.35(2 \mathrm{H}, \mathrm{dd}$, $J=8.4,1.8 \mathrm{~Hz}), 6.88(2 \mathrm{H}, \mathrm{d}, J=8.4 \mathrm{~Hz}), 4.07(4 \mathrm{H}, \mathrm{t}, J=6.6 \mathrm{~Hz}), 4.04(4 \mathrm{H}, \mathrm{t}, J=6.6 \mathrm{~Hz}), 1.93-1.77$

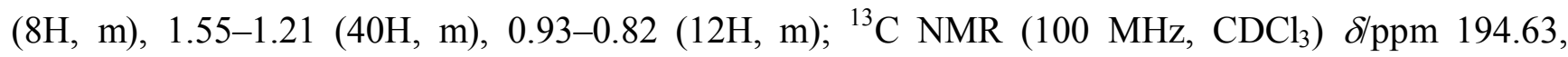
152.74, 148.64, 130.69, 124.67, 114.65, 111.50, 69.28, 69.07, 31.82, 29.35, 29.27, 29.20, 29.10, 25.99, 22.67, 14.10; IR (KBr) 2955, 2920, 2873, 2852, 1665, 1597, 1581, 1518, 1469, 1413, 1390, 1343, 1301, 1265, 1237, 1200, 1127, 1023, 1011, 964, 847, 821, 753, 721, $626 \mathrm{~cm}^{-1}$; FD-MS m/z $695\left(\mathrm{M}^{+}\right.$, BP); Anal. Calcd. for $\mathrm{C}_{45} \mathrm{H}_{74} \mathrm{O}_{5}$ : C, 77.76; H, 10.73. Found: C, 77.76; H, 10.71\%.

\subsection{Preparation of 3,3',4,4'-Tetrakis(Hexadecyloxy)Benzophenone $\mathbf{4 O}_{\mathbf{1 6}}$}

To a solution of 4-bromo-1,2-bis(hexadecyloxy)benzene $(5.01 \mathrm{~g}, 7.85 \mathrm{mmol})$ in $25 \mathrm{~mL}$ of dry ether and $25 \mathrm{~mL}$ of dry hexane was added BuLi in hexane $(1.57 \mathrm{M}, 5.00 \mathrm{~mL}, 7.85 \mathrm{mmol})$ at $23^{\circ} \mathrm{C}$ under $\mathrm{Ar}$, and the mixture was stirred for $1 \mathrm{~h}$. To the suspension was added $N$-carboethoxypiperidine $(600 \mu \mathrm{L}$, $3.89 \mathrm{mmol}$ ) and the mixture was stirred at $24{ }^{\circ} \mathrm{C}$ for $23 \mathrm{~h}$. After diluted with $3 \mathrm{M} \mathrm{HCl}$ aq., the whole mixture was extracted with $\mathrm{CH}_{2} \mathrm{Cl}_{2}$. The combined organic layers were washed with $3 \mathrm{M} \mathrm{HCl}$ aq. and $1 \mathrm{M} \mathrm{NaOH}$ aq., and dried over anhydrous $\mathrm{MgSO}_{4}$. After filtration, solvent was concentrated under reduced pressure. The residue was purified by column chromatography on silica gel $\left(\mathrm{CH}_{2} \mathrm{Cl}_{2} /\right.$ hexane $\left.=1\right)$ to give $\mathbf{4 O}_{16}(3.56 \mathrm{~g})$ as a colorless solid in $80 \%$ yield.

Mp 81.5-83.0 ${ }^{\circ} \mathrm{C} ;{ }^{1} \mathrm{H}$ NMR $\left(300 \mathrm{MHz}, \mathrm{CDCl}_{3}\right) \delta / \mathrm{ppm} 7.40(2 \mathrm{H}, \mathrm{d}, J=1.8 \mathrm{~Hz}), 7.34(2 \mathrm{H}, \mathrm{dd}$, $J=8.4,1.8 \mathrm{~Hz}), 6.88(2 \mathrm{H}, \mathrm{d}, J=8.4 \mathrm{~Hz}), 4.07(4 \mathrm{H}, \mathrm{t}, J=6.6 \mathrm{~Hz}), 4.03(4 \mathrm{H}, \mathrm{t}, J=6.6 \mathrm{~Hz}), 1.92-1.76$

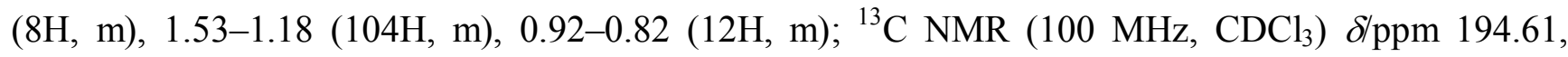
$152.74,148.64,130.69,124.67,114.65,111.49,69.28,69.07,31.93,29.71,29.64,29.43,29.37,29.20$, 29.12, 26.01, 22.68, 14.11; IR (KBr) 2956, 2917, 2849, 1661, 1597, 1579, 1518, 1468, 1432, 1414, 1392, 1342, 1266, 1237, 1200, 1125, 1030, 1016, 850, 754, 721, $625 \mathrm{~cm}^{-1}$; FD-MS m/z $1143\left(\mathrm{M}^{+}, \mathrm{BP}\right)$; Anal. Calcd. for $\mathrm{C}_{77} \mathrm{H}_{138} \mathrm{O}_{5}$ : C, 80.85; H, 12.16. Found: C, 80.73; H, 12.15\%.

\subsection{Preparation of 4-Bromo-1,2-Bis(Hexadecyloxy)Benzene}

To a solution of 1,2-bis(hexadecyloxy)benzene (14.9 g, $26.7 \mathrm{mmol}$ ) in $200 \mathrm{~mL}$ of dry $\mathrm{CH}_{2} \mathrm{Cl}_{2}$ was added $\mathrm{N}$-bromosuccinimide $(4.75 \mathrm{~g}, 26.7 \mathrm{mmol})$ in dry $\mathrm{MeCN} 70 \mathrm{~mL}$ at $23{ }^{\circ} \mathrm{C}$ under $\mathrm{Ar}$, and the mixture was stirred for $20 \mathrm{~h}$. After diluted with water, the whole mixture was extracted with $\mathrm{CH}_{2} \mathrm{Cl}_{2}$. The combined organic layers were washed with $10 \% \mathrm{Na}_{2} \mathrm{~S}_{2} \mathrm{O}_{3}$ aq. and brine, and dried over anhydrous $\mathrm{MgSO}_{4}$. After filtration, solvent was concentrated under reduced pressure. The residue was purified by column chromatography on silica gel (hexane/EtOAc $=200$ to 100 ) to give 4-bromo-1,2bis(hexadecyloxy)benzene (16.8 g) as a colorless solid in $99 \%$ yield.

Mp 62.5-63.5 ${ }^{\circ} \mathrm{C} ;{ }^{1} \mathrm{H}$ NMR (300 MHz, $\left.\mathrm{CDCl}_{3}\right) \delta / \mathrm{ppm} 7.00-6.94(2 \mathrm{H}, \mathrm{m}), 6.72(1 \mathrm{H}, \mathrm{d}, J=9.1 \mathrm{~Hz})$, $3.95(2 \mathrm{H}, \mathrm{t}, J=6.6 \mathrm{~Hz}), 3.94(2 \mathrm{H}, \mathrm{t}, J=6.6 \mathrm{~Hz}), 1.86-1.72(4 \mathrm{H}, \mathrm{m}), 1.52-1.17(52 \mathrm{H}, \mathrm{m}), 0.92-0.84$ $(6 \mathrm{H}, \mathrm{m}) ;{ }^{13} \mathrm{C} \mathrm{NMR}\left(100 \mathrm{MHz}, \mathrm{CDCl}_{3}\right) \delta / \mathrm{ppm} 150.06,148.38,123.42,116.95,115.17,112.79,69.53$, 69.38, 31.93, 29.71, 29.63, 29.38, 29.23, 29.13, 25.99, 22.70, 14.11; IR (KBr) 2917, 2848, 1588, 1509, 1503, 1468, 1446, 1434, 1392, 1324, 1258, 1220, 1132, 1066, 1014, 955, 865, 842, 826, 800, 722, 644, 
$576 \mathrm{~cm}^{-1}$; FD-MS m/z (relative intensity) $638\left(\mathrm{M}^{+}, 35\right), 636\left(\mathrm{M}^{+}, 35\right), 559(\mathrm{BP})$; Anal. Calcd. for $\mathrm{C}_{38} \mathrm{H}_{69} \mathrm{O}_{2} \mathrm{Br}$ : C, 71.55; H, 10.90. Found: C, 71.37; H, 10.80\%.

\subsection{Measurement of Redox Potentials}

All the redox potentials ( $E^{\mathrm{ox}}$ and $E^{\mathrm{red}}$ ) were measured under argon atmosphere by cyclic voltammetry in $\mathrm{CH}_{2} \mathrm{Cl}_{2}$ containing $0.1 \mathrm{M} \mathrm{Bu}_{4} \mathrm{NBF}_{4}$ as a supporting electrolyte. All the values are reported in $E / \mathrm{V} v s$. $\mathrm{SCE}$, and Pt wire was used as the working electrode. In the case of irreversible waves, half-wave potentials were estimated from the peak potentials as $E^{\mathrm{ox}}=E^{\mathrm{pa}}$ (anodic peak potential) $-0.03 \mathrm{~V}$, and $E^{\mathrm{red}}=E^{\mathrm{pc}}($ cathodic peak potential $)+0.03 \mathrm{~V}$.

\subsection{X-Ray Structural Analyses}

Unsymmetric DHP 1NX: $\mathrm{C}_{42} \mathrm{H}_{36} \mathrm{~N}_{2} \mathrm{O}, M 584.76,0.60 \times 0.10 \times 0.05 \mathrm{~mm}$, orthorhombic, space group $P 2{ }_{1} 2_{1} 2_{1}, a=10.4511(4), b=14.0601(7), c=20.771(1) \AA, V=3052.2(3) \AA[3,4]$, and $D_{\text {calcd }}$ $(\mathrm{Z}=4)=1.272 \mathrm{~g} \mathrm{~cm}^{-3}$. Numerical absorption correction was applied $\left(\mu=0.76 \mathrm{~cm}^{-1}\right)$. Data collection was performed on a Rigaku Mercury CCD camera appararus (Mo-K $\alpha$ radiation, $\lambda=0.71069 \AA, 50 \mathrm{kV}$, $50 \mathrm{~mA}$ ) at $203 \mathrm{~K}$. The structure was solved by the direct method and refined by full-matrix least-squares method on $F$ with anisotropic temperature factors for non-hydrogen atoms. Hydrogen atoms were located at the calculated positions. The final $R$ and $R w$ values are 0.044 and 0.049 for 407 parameters and 2835 reflections with $I>3 \sigma(I)$ (independent reflections, $3625 ; 2 \theta_{\max }=53.5^{\circ}$ ). The GOF indicator is 1.20 . Residual electron density is $0.16 \AA^{-3}$. CCDC $182 / 1003$

\section{Acknowledgments}

The authors gratefully acknowledge financial support from a Grant-in-Aid for Scientific Research on Innovative Areas “Organic Synthesis Based on Reaction Integration” by MEXT, Japan.

\section{References}

1. Monk, P.M.S.; Mortimer, R.J.; Rosseinsky, D.R. Electrochromism and Electrochromic Devices; Cambridge University Press: Cambridge,MA, USA and New York, NY, USA, 2007.

2. Muthyala, R. Chemistry and Application of Leuco Dyes; Plenum Press: New York, NY, USA and London, UK, 1997.

3. Suzuki, T.; Higuchi, H.; Tsuji, T.; Nishida, J.; Yamashita, Y.; Miyashi, T. Chemistry of Nanomolecular Systems. Chapter 1: Dynamic Redox Systems; Nakamura, T., Matsumoto, T., Tada, T., Sugiura, K., Eds.; Springer: Heidelberg, Germany, 2003; pp. 3-24.

4. Suzuki, T.; Ohta, E.; Kawai, H.; Fujiwara, K.; Fukushima, T. Dynamic redox systems as electrochromic materials: Bistability and advanced response. Synlett (Account) 2007, 38, 851-869.

5. Suzuki, T.; Nishida, J.; Tsuji, T. Hexaphenylethane derivatives exhibiting novel electrochromic behavior. Angew. Chem. Int. Ed. Engl. 1997, 36, 1329-1331.

6. Suzuki, T.; Nishida, J.; Tsuji, T. A new type of tricolor electrochromic system based on the dynamic redox properties of hexaarylethane derivatives. Chem. Commun. 1998, 20, 2193-2194. 
7. Suzuki, T.; Ishigaki, Y.; Iwai, T.; Kawai, H.; Fujiwara, K.; Ikeda, H.; Kano, Y.; Mizuno, K. Multi-input/multi-output molecular response system based on the dynamic redox behavior of 3,3,4,4-tetraaryldihydro[5]helicene derivatives: Reversible formation/destruction of chiral fluorophore and modulation of chiroptical properties by solvent polarity. Chem. Eur. J. 2009, 15, 9434-9441.

8. Jähnisch, K.; Hessel, V.; Löwe, H.; Baerns, M. Chemistry in microstructured reactors. Angew. Chem. Int. Ed. 2004, 43, 406-446.

9. Doku, G.N.; Verboom, W.; Reinhoudt, D.N.; van den Berg, A. On-microchip multiphase chemistry-A review of microreactor design principles and reagent contacting modes. Tetrahedron 2005, 61, 2733-2742.

10. Watts, P.; Haswell, S.J. The application of micro reactors for organic synthesis. Chem. Soc. Rev. 2005, 34, 235-246.

11. Yoshida, J. Flash chemistry using electrochemical method and microsystems. Chem. Commun. 2005, 36, 4509-4516.

12. Geyer, K.; Codee, J.D.C.; Seeberger, P.H. Microreactors as tools for synthetic chemists-The chemists' round-bottomed flask of the 21 st century? Chem. Eur. J. 2006, 12, 8434-8442.

13. De Mello, A.J. Control and detection of chemical reactions in microfluidic systems. Nature 2006, 442, 394-402.

14. Song, H.; Chen, D.L.; Ismagilov, R.F. Reactions in droplets in microfluidic channels. Angew. Chem. Int. Ed. 2006, 45, 7336-7356.

15. Kobayashi, J.; Mori, Y.; Kobayashi, S. Multiphase organic synthesis in microchannel reactors. Chem. Asian. J. 2006, 1, 22-35.

16. Mason, B.P.; Price, K.E.; Steinbacher, J.L.; Bogdan, A.R.; McQuade, D.T. Greener approaches to organic synthesis using microreactor technology. Chem. Rev. 2007, 107, 2300-2318.

17. Ahmed-Omer, B.; Brandtand, J.C.; Wirth, T. Advanced organic synthesis using microreactor technology. Org. Biomol. Chem. 2007, 5, 733-740.

18. Fukuyama, T.; Rahman, M.T.; Sato, M.; Ryu, I. Adventures in inner space: Microflow systems for practical organic synthesis. Synlett 2008, 2, 151-163.

19. Yoshida, J.; Nagaki, A.; Yamada, T. Flash chemistry: Fast chemical synthesis by using microreactors. Chem. Eur. J. 2008, 14, 7450-7459.

20. Neugebauer, N.; Kos, A.J.; Schleyer, P.R. Regioselektive dimetallierung von aromaten. Bequemer zugang zu 2,2'-disubstituierten biphenylderivaten. J. Organomet. Chem. 1982, 228, 107-118.

21. Leroux, F.; Nicod, N.; Bonnafoux, L.; Quissac, B.; Colobert, F. New vistas in halogen/metal exchange reactions: The discrimination between seemingly equal halogens. Lett. Org. Chem. 2006, 3, 165-169.

22. Nagaki, A.; Takabayashi, N.; Tomida, Y.; Yoshida, J. Selective monolithiation of dibromobiaryls using microflow systems. Org. Lett. 2008, 10, 3937-3940.

23. Nagaki, A.; Takabayashi, N.; Tomida, Y.; Yoshida, J. Synthesis of unsymmetrically substituted biaryls via sequential lithiation of dibromobiaryls using integrated microflow systems. Beilstein J. Org. Chem. 2009, 5, doi:10.3762/bjoc.5.16. 
24. Usutani, H.; Tomida, Y.; Nagaki, A.; Okamoto, H.; Nokami, T.; Yoshida, J. Generation and reactions of $o$-bromophenyllithium without benzyne formation using a microreactor. J. Am. Chem. Soc. 2007, 129, 3046-3047.

25. Nagaki, A.; Tomida, Y.; Usutani, H.; Kim, H.; Takabayashi, N.; Nokami, T.; Okamoto, H.; Yoshida, J. Integrated micro flow synthesis based on sequential br-li exchange reactions of $p$-, $m$-, and $o$-dibromobenzenes. Chem. Asian J. 2007, 2, 1513-1523.

26. Suga, S.; Yamada, D.; Yoshida, J. Cationic three-component coupling involving an optically active enamine derivative. From time integration to space integration of reactions. Chem. Lett. 2010, 39, 404-406.

27. Allen, F.H.; Kennard, O.; Watson, D.G.; Brammer, L.; Orpen, A.G.; Taylor, R. Tables of bond lengths determined by X-ray and neutron diffraction. Part 1. Bond lengths in organic compounds. J. Chem. Soc. Perkin Trans. 2 1987, 12, S1-S19.

28. Kahr, B.; Engen, D.V.; Mislow, K. Length of the ethane bond in hexaphenylethane and its derivatives. J. Am. Chem. Soc. 1986, 108, 8305-8307.

29. Suzuki, T.; Takeda, T.; Kawai, H.; Suzuki, T. Ultralong C-C bonds in hexaphenylethane derivatives. Pure Appl. Chem. 2008, 80, 547-553.

30. Kawai, H.; Takeda, T.; Fujiwara, K.; Wakeshima, M.; Hinatsu, Y.; Suzuki, T. Ultralong carbon-carbon bonds in dispirobis(10-methylacridan) derivatives with an acenaphthene, pyracene, or dihydropyracylene skeleton. Chem. Eur. J. 2008, 14, 5780-5793.

31. Takeda, T.; Kawai, H.; Herges, R.; Mucke, E.; Sawai, Y.; Fujiwara, K.; Suzuki, T. Negligible diradical character for the ultralong $\mathrm{C}-\mathrm{C}$ bond in 1,1,2,2-tetraarylpyracene derivatives at room temperature. Tetrahedron Lett. 2009, 50, 3693-3697.

32. Dyker, G.; Körning, J.; Bubenitschek, P.; Jones, P.G. Palladium-catalyzed synthesis of propellanes with hexaarylethane structure. Liebigs Ann. Recl. 1997, 1, 203-209.

33. Maslak, P.; Chapman, W.H., Jr.; Vallombroso, T.M., Jr.; Watson, B.A. Mesolytic Scission of C-C bonds in radical cations of amino derivatives: Steric and solvent effects. J. Am. Chem. Soc. 1995, 117, 12380-12389.

34. Huang, L.-T.; Yen, H.-J.; Chang, C.-W.; Liou, G.-S. Red, green, and blue electrochromism in ambipolar poly(amine-amide-imide)s based on electroactive tetraphenyl-p-phenylenediamine units. J. Polymer Sci. 2010, 48, 4747-4757.

35. Koyuncu, S.; Zafer, C.; Sefer, E.; Koyuncu, F.B.; Demic, S.; Kaya, I.; Ozdemir, E.; Icli, S. A new conducting polymer of 2,5-bis(2-thienyl)-1H-(pyrrole) (SNS) containing carbazole subunit: Electrochemical, optical and electrochromic properties. Synth. Met. 2009, 159, 2013-2021.

36. Zeng, Q.; McNally, A.; Keyes, T.E.; Forster, R.J. Redox induced switching dynamics of a three colour electrochromic metallopolymer film. Electrochim. Acta 2008, 53, 7033-7038.

37. Ozyurt, F.; Gunbas, E.G.; Durmus, A.; Toppare, L. Processable and multichromic polymer of bis-3-hexylthiophene substituted 4-tert-butylphenyl quinoxaline. Org. Elect. 2008, 9, 296-302.

38. Zeng, Q.; McNally, A.; Keyes, T.E.; Forster, R.J. Three colour electrochromic metallopolymer based on a ruthenium phenolate complex bound to poly(4-vinyl)pyridine. Electrochem. Commun. 2008, 10, 466-470. 
39. Li, X.-G.; Wang, H.-Y.; Huang, M.-R. Synthesis, film-forming, and electronic properties of o-phenylenediamine copolymers displaying an uncommon tricolor. Macromolecules 2007, 40, 1489-1496.

40. Thompson, B.C.; Kim, Y.-G.; McCarley, T.D.; Reynolds, J.R. Soluble narrow band gap and blue propylenedioxythiophene-cyanovinylene polymers as multifunctional materials for photovoltaic and electrochromic applications. J. Am. Chem. Soc. 2006, 128, 12714-12725.

41. Sonmez, G.; Wudl, F. Completion of the three primary colours: The final step toward plastic displays. J. Mat. Chem. 2005, 15, 20-22.

42. Yano, J.; Yamasaki, S. Three-color electrochromism of an aramid film containing polyaniline and poly(o-phenylenediamine). Synth. Met. 1999, 102, 1157.

43. Sotzing, G.A.; Reddinger, J.L.; Katritzky, A.R.; Soloducho, J.; Musgrave, R.; Reynolds, J.R.; Steel, P.J. Multiply colored electrochromic carbazole-based polymers. Chem. Mat. 1997, 9, 1578-1587.

44. Yano, J.; Terayama, K.; Yamasaki, S. Electrochemically prepared poly(o-phenylenediamine)—Prussian blue composite film for a three-colour expressible ECD material. J. Mat. Sci. 1996, 31, 4785-4792.

45. Yamasaki, S.; Terayama, K.; Yano, J. Poly(p-phenylene terephthalamide) film immobilizing oligomer species as a colored matrix for three-color electrochromic displays. J. Electrochem. Soc. 1996, 143, L212-L214.

46. Yang, J.; Kai, S.; Ogura, K. Poly(o-phenylenediamine)-Prussian blue composite film for a three-colour-expressible electrochromic display material. J. Mat. Sci. Lett. 1993, 12, 1791-1792.

47. Sugimoto, T.; Nagatomi, T.; Ando, H.; Yoshida, Z. Redox-active thieno[3,2-b]thiophene as a novel, three-color electrochromic system. Angew. Chem. Int. Ed. Engl. 1988, 27, 560-561.

48. Li, X.-G.; Wang, H.-Y.; Huang, M.-R. Synthesis, film-forming, and electronic properties of $o$-phenylenediamine copolymers displaying an uncommon tricolor. Macromolecules 2007, 40, 1489-1496.

49. Zeng, Q.; McNally, A.; Forster, R.J. Redox induced switching dynamics of a three colour electrochromic metallopolymer film. Electrochem. Acta 2008, 53, 7033-7038.

50. Deng, W.; Flood, A.H.; Stoddart, J.F.; Goddard, W.A., III. An electrochemical color-switchable rgb dye: Tristable [2]catenane. J. Am. Chem. Soc. 2005, 127, 15994-15995.

51. Ikeda, T.; Saha, S.; Aprahamian, I.; Leung, K.C.F.; Williams, A.; Deng, W.; Flood, A.H.; Goddard, W.A., III; Stoddart, J.F. Toward electrochemically controllable tristable three-station [2]catenanes. Chem. Asian J. 2007, 2, 76-93.

52. Nishida, J.; Suzuki, T.; Ohkita, M.; Tsuji, T. A redox switch based on dihydro[5]helicene: Drastic chiroptical response induced by reversible $\mathrm{C}-\mathrm{C}$ bond making/breaking upon electron transfer. Angew. Chem. Int. Ed. 2001, 40, 3251-3254.

53. Suzuki, T.; Yamamoto, R.; Higuchi, H.; Hirota, E.; Ohkita, M.; Tsuji, T. Electrochiroptical response of a hexaarylethane derivative with a helical $\pi$-skeleton: Drastic UV-Vis and CD spectral changes upon electrolysis of 4',5'-dibromodispiro[xanthene-9, $9^{\prime}\left(9^{\prime} H, 10^{\prime} H\right)$-phenanthrene10',9"-xanthene]. J. Chem. Soc. Perkin Trans. 2002, 2, 1937-1942. 
54. Suzuki, T.; Iwai, T.; Ohta, E.; Kawai, H.; Fujiwara, K. Electrochiroptical systems based on biphenyl-2,2'-diyl-type dicationic dyes: Strong chiroptical signals through the transmission of point chirality to axial chirality. Tetrahedron Lett. 2007, 48, 3599-3603.

(C) 2011 by the authors; licensee MDPI, Basel, Switzerland. This article is an open access article distributed under the terms and conditions of the Creative Commons Attribution license (http://creativecommons.org/licenses/by/3.0/). 